\title{
The U.S.-Lithuanian Defense Cooperation and Arms Acquisition from the U.S.
}

\section{Donatas Palavenis $^{1}$}

\begin{abstract}
The aim of the study is to characterize the U.S. and Lithuanian defense cooperation from 1990-2020 including arms procurements. Findings suggest close defense cooperation between countries at Presidential, Congressional, and Defense Ministry/Secretary levels. The most developed cooperation areas are joint participation in international operations, improvements of the Lithuanian Armed Forces' capabilities, and an increase of the U.S. military presence in the Baltic region. An analysis of Lithuanian defense procurements between 1990-2020 indicates that the majority of defense armaments were acquired from the U.S. using the Foreign Military Sales venue while other options to obtain armaments were not used.
\end{abstract}

Keywords: National Security Strategy, Defense Policy, Arms Sales, Defense Cooperation Security Agency, Foreign Military Sales

\section{Introduction}

The course of defense cooperation between countries can reveal some principal characteristics of their relationship. For example, the U.S. is one of the key security guarantors for Lithuania as well as for the Baltic States. Since its re-establishment of independence in 1990, Lithuania has gradually aimed towards enhancing its cooperation with the U.S., particularly regarding cooperation in the defense field. Over the last three decades, specifics of cooperation on various defense topics have been discussed in President, and Defense Minister or Secretary (Lithuanian and the U.S., respectively) level meetings, and were further implemented in the Agreements and/or published in the respective National Laws referencing defense and security. One of the bilateral interests in defense cooperation is the development of the sustained capability of the Lithuanian Armed Forces (LAF) which includes the procurement of required armaments, ammunition, and equipment. As a major arms producer and exporter, the U.S. is capable of both recommending modern equipment for a reasonable price, while sometimes even offering to cover a portion or all of the cost for

\footnotetext{
${ }^{1}$ General Jonas Žemaitis Military Academy of Lithuania, Šilo str. 5A, LT-10322 Vilnius, Lithuania; +370 604 58832; donatas.palavenis@gmail.com; ORCID ID: 0000-0003-0908-7512.

Major Donatas Palavenis is an officer of the Lithuanian Armed Forces, and a PhD candidate at General Jonas Žemaitis Military Academy of Lithuania. His main interests are research of defense industry in regards to small NATO/EU countries, and their defense policies, defense procurements, and defense economics.
} 
various equipment. The growing Lithuanian defense budget and the U.S. support programs have opened new opportunities for the Lithuanian Ministry of Defense (MoD) to acquire armaments on the international market.

The intent of this study is to characterize the U.S. and Lithuanian defense cooperation with focus on Lithuanian armament procurement from the U.S. The analysis provided explains the cooperation as it has progressed from March 1990 to May 2020 using content and comparison analyses of primary and secondary data. This is the first time bilateral defense cooperation and Lithuanian armament procurement have been analyzed in regards to the given timeframe and detail in this study.

In general, the topic of the U.S.--Lithuanian relationship has been of scientific interest, but the majority of studies have used a broader approach looking at the perspective of the entire region of the Baltic States. Gerda Jakštaite (Jakstaite, 2019; 2011; 2014) analyzed bilateral relation aspects during different periods (Clinton vs Obama; 2013-2014; post-2014), focused on the military domain and indicated there were positive changes from the U.S. strategies towards Lithuania. Vaidotas Urbelis (Urbelis, 2003; 2005) analyzed the U.S. Grand Strategy and its effect on Lithuania prior to 2004, explaining the evolution of LAF and its involvement in international operations. The author concluded that Lithuania would mostly follow U.S. policies and strive to meet the bare minimum requirements of EU policies merely to remain in compliance. Similar findings could be found in a Marko Lehti (2007) study where he concluded that the Baltic States, instead of being 'protégé's of the U.S.', are transforming into intermediaries between Brussels and Washington. Margarita Šešelgyte (2013) concluded that Lithuania is a trans-Atlantic military activist, however, limited in its resources. Sigita Trainauskienè (2013) applied some of her focus towards transatlantic relation issues for Lithuanian security and concluded that Lithuania needed to invest with the U.S. in the development of defensive capabilities because the U.S. was shifting its attention to Asia. Renatas Norkus (1999) analyzed bilateral developments including military cooperation during the period of 1996-1999. Derek E. Mix (2020) concluded that cooperation between the Baltic States and the U.S. must focus on security, energy and economic sectors, and building LAF capabilities. Lithuanian MoD policies were analyzed by Algirdas Orenius (2015) for the period of 1990-2002. Erik Männik (2013) assessed the Baltic States security strategies during the period from 2002-2012 and concluded that close defense cooperation between the Baltic and Nordic countries would evolve, but will not replace a bilateral relationship with the U.S. Some of the authors focused their attention on the specific defense cooperation venues such as Host Nation Support (HNS), and the Defense 
Cooperation Agreement (DCA). Valdis Otzulis and Žaneta Ozoliņa (2017) discussed HNS issues in the Baltic States. Benjámin Baksa (2019) examined the U.S. and Eastern European DCAs. Moreover, many studies in the post-2014 period were carried out by Think tanks, such as RAND, ICDS, the Atlantic Council, the Hoover Institution, and the Heritage Foundation on a wide scale of topics including resilience of the Baltic States, future defense cooperation, and the need for defense capabilities.

This manuscript is structured in two parts. The first part describes a retrospective of bilateral defense cooperation, and analyzes national strategic documents, outcomes of the Presidential and Defense Ministerial/Secretary level meetings, and the content of the bilateral agreements. Furthermore, venues of defense cooperation are identified and analyzed. The second part focuses more specifically on U.S.-Lithuanian defense cooperation, i.e. armament procurements. It provides a revision of the Lithuanian defense budget, as well as an analysis of armament procurements from the U.S. indicating possible future acquisitions by LAF in the eight years following 2020. The discussion covers current and future armament procurement options that ought to be reconsidered in the light of the methods previously chosen by several NATO countries.

\section{Retrospective of the U.S. and Lithuanian Defense Cooperation}

It is critical to start this part with the historical note that on 23 July 1940, the U.S. Under Secretary of State, Sumner Welles, stated in his Declaration that the U.S. rejected the forcible incorporation of Lithuania and the other Baltic States into the Soviet Union (Derse, 2015). Therefore, it was noticeable to all that the U.S. had a moral obligation to support the rise of reborn Baltic States in the 1990s by facilitating their path towards a better future. This in fact encouraged the leaders of Estonia, Latvia, and Lithuania to seek out the support of the U.S.

The Lithuanian Embassy in the U.S. was reopened following the proclamation of independence on 11 March 1990. After the August Coup in Moscow which occurred from 19-22 August 1991, the U.S. then recognized the restoration of Lithuania's independence on 2 September 1991. The establishment of the U.S. Embassy in Vilnius started on October 2 1991, and the U.S. Defense Attaché to Lithuania was assigned in 1992. The Lithuanian Defense Attaché to the U.S. was later assigned in 1995 (Grina, 2017; KA, 2005; MoFA, 2020; OH, 2020; Seimas, 1993).

The first U.S. ship 'Hawes' embarked on the Lithuanian seaport in Klaipeda (Figure 1) on 1 July 1992. The U.S. Army liaison team led by Colonel Robert Barziloski started the 
program 'Soldier for Soldier' in April 1993. The first results of newly established cooperation became evident when the Lithuanian fleet successfully participated in NATO and the U.S. exercises 'BALTOPS 93' in mid-June 1993. Therefore, it is obvious initial defense cooperation was initiated between the U.S. and Lithuania even before 'the last Russian soldier' withdrew from Lithuania on 31 August 1993. The initial perception of Lithuania being a neutral country changed to it being a nation aspiring to join NATO as of 4 January 1994 when the President of Lithuania sent a letter to the NATO Secretary General expressing the desire to become a NATO member. On 27 January 1994, Lithuania joined the Partnership for Peace (PfP) program. The PfP program was an idea brought about by the U.S. in the autumn of 1993 with the concept of bringing the militaries of East European countries into compliance with NATO standards. The more formal level of bilateral defense cooperation was reached on 16 January 1998 when the Baltic Charter was signed between the U.S. and the Baltic States.
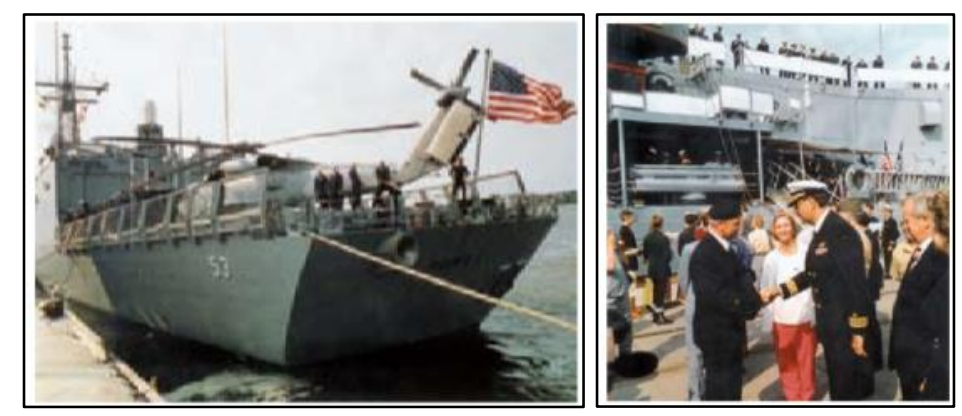

Figure 1. The U.S. ship 'Hawes' embarked the Lithuanian seaport in Klaipeda on 1 July 1992; Commander of the U.S. ship 'Hawes' Frens Demasi (on the right) was met by the Deputy Border Guard Regiment Vytautas Urbas (on the left) (Kažerskas, Brencius, \& Vitkauskas, 2012)

From 1994 to the present, Lithuanian troops have been actively engaged in NATO, UN, and U.S. led international peacekeeping and combat support missions. The most notable achievement to date was when Lithuanian soldiers and civilians were placed in charge of the Provincial Reconstruction Team (PRT) in the Ghor Province in Afghanistan from 2005-2013. Following the aggressive actions by Russian Federation towards Georgia in August 2008 and the annexation of Crimea in the Ukraine in 2014, U.S. leadership reassured Lithuania it was committed to providing support as agreed upon under NATO Article 5. Soon after the Ukrainian crisis, the U.S. deployed additional fighters and rotational ground troops to the Baltic Region, increased the number of exercises, and prepositioned military equipment to deter Russian aggression. NATO has evolved to take over some of the U.S. burden, but the U.S. presence appears that it will remain in Lithuania for the foreseeable future (Jakštaitè, 2011; KA, 2005; Mix, 2020; WH, 2014). 
Amongst the bilateral cooperation that remains continuous and intense between the U.S. and Lithuania, the defense cooperation is a part that is consistently one of the primal topics. The U.S. support for Lithuania's aspiration to become a NATO member and to be an active participant in deterrence activities in the Baltic Sea region since 2014 has been reciprocated by the Lithuanian loyalty demonstrated during participation in U.S. led international operations.

\subsection{National strategies vis-à-vis practical bilateral defense cooperation}

Defense cooperation is affirmed by each country's continued resolute stature in regards to their policies, strategies, or doctrines. An analysis over the time of these documents brings to light the intent to sustain this cooperation (Table 1).

Table 1. Release dates of the U.S. and Lithuanian documents framing bilateral military cooperation

\begin{tabular}{|c|c|c|c|c|c|c|c|c|c|c|c|c|c|c|c|c|c|c|c|c|c|c|c|c|c|c|c|c|c|c|}
\hline \multicolumn{2}{|r|}{ Document } & \& & $\bar{\sigma}$ & 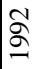 & $\tilde{\Omega}$ & ఫે & $\stackrel{2}{2}$ & ڤั & $\hat{\sigma}$ & $\stackrel{\infty}{2}$ & Әे & ஓ्ন & ஓ्̀े & శ్రి & 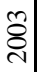 & 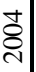 & 怘 & 斊 & ڤ્ટે & 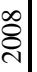 & 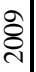 & & & 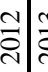 & 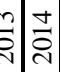 & $\mid$ & & $\left.\right|_{\vec{N}} ^{\infty} \stackrel{\infty}{\Sigma}$ & 리 & 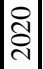 \\
\hline \multirow{3}{*}{ 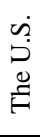 } & National Security Strategy & - & $\bullet$ & & $\bullet$ & - & - & $\bullet$ & $\bullet$ & $\bullet$ & $\bullet$ & $\bullet$ & & $\bullet$ & & & & $\bullet$ & & & & $\bullet$ & & & & $\bullet$ & & $\bullet$ & & \\
\hline & National Defense Strategy & & & & & & & & $\bullet$ & & & & $\bullet$ & & & & - & - & & - & & $\bullet$ & & & - & & & - & & \\
\hline & National Military Strategy & & & - & & & - & & - & & & & & & & - & & & & & & & - & & & - & & - & & \\
\hline \multirow{5}{*}{ 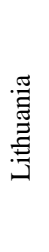 } & $\begin{array}{l}\text { Law on the Basics of National } \\
\text { Security }\end{array}$ & & & & & & & 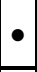 & & & & & & & & & & & & & & & & & & & & & & \\
\hline & National Security Strategy & & & & & & & & & & & & & $\bullet$ & & & - & & & & & & & - & & & & • & & \\
\hline & Military Strategy & & & & & & & & & & & - & & $\bullet$ & & - & & & & & & & & - & & & - & & & \\
\hline & MoD Guidelines & & & & & & & & & & & & & & & & & & & & - & & & - & $\bullet$ & & - & • & & \\
\hline & MoD Strategic activity plan & & & & & & & & & & & & & & & & - & - & & & - & - & - & - & - & & & • & - & \\
\hline
\end{tabular}

The U.S. documents mentioned in Table 1, including the National Defense Strategy (NDS), also referred to as Quadrennial Defense Review (QDR), are used for this analysis as the contents indicate strategic reasons for such intense bilateral military cooperation and give reference to particular cooperation venues. The analysis of Lithuanian documents, which include the Law on the Basics of National Security (LBNS), may also be seen as a reference to anticipated venues of defense cooperation with the U.S.

\subsubsection{Lithuanian footprint in the main U.S. documents related to the Security and Defense}

\section{Strategies}

The U.S. National Security Strategy (NSS) outlines the major national security concerns and threats and expresses how to deal with them. The U.S. NSS does not mention Lithuania in detail. Lithuania is only subtly mentioned in the general context of the Baltic States in the protocols of NSS from the years 1997, 1998, 1999, 2000, and 2015. If taken from the context of other U.S. NSS or documents such as the NDS/QDR, or National Military Strategy (NMS), it is assumed that Lithuania is seen as either a part of Eastern Europe, as a 
state of the former Soviet Union, or as a European ally. The U.S. NSS indicates the U.S. has had the following intentions or views towards Lithuania over the last three decades: a) promotion of the state's self-determination and support for its reforms towards democracy in 1990-1993 (WH, 1990; 1991; 1993); b) support for integration into NATO and the World Trade Organization, and support for democratic reforms and movement towards a free market, which was required to support peace efforts in troubled regions in 1994-2000 (WH, $1994 ; 1996 ; 1997 ; 1998 ; 1999 ; 2000)$; c) requirement to support the War on Terrorism, and continued expansion of a free market in 2002-2010 (Bush, 2002; 2006; Obama, 2010); d) support for Lithuanian security, a requirement to support the continuous fight against extremists and terrorists, and increase defense spending in 2015-2017 (Obama, 2015; Trump, 2017).

In the U.S. NDS/QDR, there are specified bilateral cooperation aspects mentioned at the Department of Defense (DoD) level. The QDR released in 1997 promoted the benefits of regional stability and praised NATO leadership for increasing the size of the Alliance. The 2001 QDR and 2005 NDS both specified the requirement for the U.S. military to strengthen existing alliances and partnerships (DoD, 1997; 2001; 2005). The QDR released in 2006 informed about expanded DoD authority to lease or lend equipment to other countries. In 2008, the NDS continued with the idea of strengthening alliances and proposed the U.S. military to transfer its capabilities to the Allies. The QDR in 2010 reaffirmed the commitment to Article 5 to develop European missile defense capabilities, and maintain a robust U.S. military presence in Europe (DoD, 2006b; 2008; 2010). In 2014, the QDR foresaw strengthening of the military capabilities of European Allies by maintaining forwardpositioned forces and training with NATO Allies. In the 2018 edition of the NDS, the U.S. expected Allies and partners to contribute an adequate share to the collective security. Also, it was highlighted that Allies could request to purchase U.S. military equipment as it would accelerate the ability to integrate with the U.S. Forces (DoD, 2014; 2018).

The U.S. NMS was delivered to the Secretary of Defense outlining the strategic aims of the U.S. Armed Forces. The NMS released in 1992 and 1995 focused on the potential political and economic instabilities in Eastern Europe. The NMS issued in 1995 highlighted the priority to develop the militaries of Central and Eastern Europe. The NMS delivered in1997 focused on the execution of the PfP initiative, foreign military sales, and International Military Education and Training. The 2004 NMS focused on the War on Terrorism and stressed the necessity to increase Allies' and partner's capabilities, to cooperate during joint operations. The NMS released in 2011, 2015, and 2018 changed the focus towards security in 
Europe, in space and cyberspace security, and onto Ballistic Missile Defense. The NMS posted in 2015 touched on U.S. operation Atlantic Resolve, the European Reassurance Initiative (ERI), support for NATO's Readiness Action Plan, exercises, and investments. The NMS issued in 2018 continued to seek greater interoperability among Allies/partners, highlighting the necessity to enhance their combat lethality (JCoS, 1992; 1995; 1997; 2004; $2011 ; 2015 ; 2018)$.

\subsubsection{How do the main Lithuanian documents related to the National Security Strategies define its military cooperation intentions with the U.S.?}

LBNS defines the national security system, regulations, and its instruments. The law highlights military interoperability with NATO forces as a key requirement for LAF (Miniotaite, 2007; Seimas, 2019). The U.S. is not mentioned specifically in the LBNS.

Lithuanian National Security Strategy (LNSS) details the tasks deriving from the LBNS. All released LNSS's highlight the U.S. as a strategic partner. The LNSS from 2002 and 2005 acknowledge Lithuanian support for the anti-terrorist coalition led by the U.S. and sought to strengthen transatlantic cooperation. The LNSS released in 2005 informs that Lithuania is actively participating in the U.S. initiative of the Enhanced Partnership in Northern Europe and the Council of the Baltic Sea States. The LNSS released in 2012 and 2017 state that the U.S. in NATO and its military presence in Europe are the key guarantees for Lithuanian security (Seimas, 2002b; 2005; 2012; 2017a).

Lithuanian Military Strategy (LMS) establishes the ways of using LAF to implement State security and defense policy goals. LMS editions from 2000 and 2002 highlight the U.S. importance for European security with references to the Baltic Charter. The LMS edition from 2004 focuses on the need for military cooperation as it would allow LAF to strengthen relations with a strategic partner. In the 2012 LMS edition, it mentions a need to have close bilateral defense cooperation with the U.S. In the 2016 LMS edition, the U.S. is mentioned in greater detail, e.g. Lithuania sees the U.S. military presence in Europe and the Baltic region, and LAF have to retain close bilateral defense cooperation with the U.S. (LMoD, 2004; 2012c; 2016b; Miniotaite, 2007).

More practicalities of bilateral defense cooperation could be found in two main documents circulated at the MoD level; the Guidelines of Minister of Defense (MoD Guidelines), and the MoD Strategic Activity Plan (MoD Plan). MoD Guidelines define priorities of the Lithuanian National Defense System (LNDS) and results to be achieved in the medium-term. In the MoD Guidelines edition of 2009 and 2012, bilateral cooperation 
with the U.S. was seen only in terms of ensuring LAF participation in international operations. MoD Guidelines for 2014 seek greater U.S. military presence in the region while tasking LAF to organize regularly scheduled exercises. Guidelines for 2016 feature one additional cooperation venue - support for U.S. European Command contingency planning. MoD Guidelines for 2017 are the most descriptive in regards to cooperation as they require the permanent presence of the U.S. troops in Lithuania, active involvement in ongoing exercises, greater support in enhancing LAF capabilities, Think tanks, and synchronization of bilateral and national defense plans (LMoD, 2009a; 2012b; 2014c; 2016a; 2017d).

The MoD Plan covers 3 years worth of perspectives and is based on how financial allocations are to be used in each particular program. The MoD Plan provides the most details regarding ongoing bilateral military cooperation between the U.S. and Lithuanian militaries. According to MoD Plans, Lithuania is willing to participate in the U.S. lead coalitions during international operations, and to provide HNS if the U.S. troops are to be deployed to Lithuania. However, requirements from Lithuania towards the U.S. differed and could be grouped into two periods, more specifically, pre-2014, and post-2014. In the pre-2014 period, the Lithuanian MoD was focused on administering support via the U.S. Foreign Military Fund (FMF) which was looking to deepen defense cooperation starting in 2010. In all post2014 MoD Plans, it was stressed to seek the U.S. military presence in Europe and the Baltic region, and to look for financial and advisory support from the U.S. Moreover, post-2014 MoD Plans provide specific details of bilateral defense cooperation such as names and dates of exercises, projects supported by FMF, and cooperation details among various U.S. and Lithuanian military headquarters (LMoD, 2005; 2006; 2009b; 2010a; 2011a; 2012a; 2014a; 2017c; 2019c).

\subsubsection{How do national strategies foresee bilateral defense cooperation?}

The analysis of the U.S. and Lithuanian documents (Table 1) that frame bilateral military cooperation identified the ten most frequently mentioned cooperation venues (Table 2). However, it is important to note that some of the venues were relevant only during a certain period. 
Table 2. Main venues of bilateral defense cooperation

\begin{tabular}{|c|c|c|c|c|c|c|c|c|c|c|c|}
\hline \multicolumn{2}{|c|}{ Documents } & \multirow{2}{*}{ 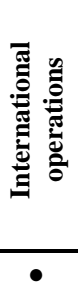 } & \multirow{2}{*}{ 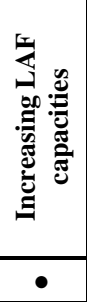 } & \multirow{2}{*}{ 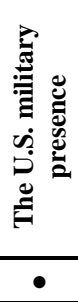 } & \multirow{2}{*}{ 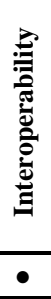 } & \multirow{2}{*}{ 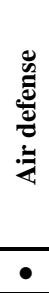 } & \multirow{2}{*}{ 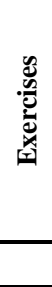 } & \multirow[t]{2}{*}{$\underline{z}$} & \multirow{2}{*}{ 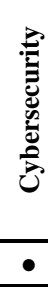 } & \multirow{2}{*}{ 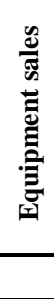 } & \multirow{2}{*}{ 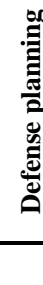 } \\
\hline \multirow{3}{*}{$\stackrel{\Xi}{E} \dot{0}$} & NSS & & & & & & & & & & \\
\hline & NDS/QDR & - & $\bullet$ & - & $\bullet$ & $\bullet$ & $\bullet$ & & & - & - \\
\hline & NMS & $\bullet$ & $\bullet$ & & $\bullet$ & $\bullet$ & $\bullet$ & & $\bullet$ & $\bullet$ & \\
\hline \multirow{5}{*}{ } & LBNS & & & & & & & & & & \\
\hline & LNSS & $\bullet$ & $\bullet$ & - & & & & - & - & & \\
\hline & LMS & $\bullet$ & $\bullet$ & $\bullet$ & $\bullet$ & & & $\bullet$ & & & \\
\hline & MoD Guidelines & $\bullet$ & $\bullet$ & $\bullet$ & & & $\bullet$ & $\bullet$ & & & $\bullet$ \\
\hline & MoD Plan & - & $\bullet$ & - & & - & - & $\bullet$ & & - & - \\
\hline
\end{tabular}

Most of the U.S. and Lithuanian DoD/MoD strategic documents reveal that the following three venues were the most important for attaining bilateral military cooperation: 1) participation in international operations; 2) increasing LAF capabilities; and 3) the U.S. military presence in Europe and the Baltic region. Another six cooperation areas were of particular U.S. interest but reflected more towards some of the Lithuanian strategies or MoD documents. Only one venue of cooperation that is of vital importance for Lithuania as a host is HNS, therefore it has no specific relevance on the U.S. documents.

\subsection{Messages related to Defense cooperation at the U.S. and Lithuanian Presidents' engagements}

During the last three decades, there were multiple Presidential engagements in a bilateral, quadrilateral, or other formats which included official and non-official arrangements (Table 3). Delegations from the U.S. House of Representatives, the U.S. Senate, the U.S. Department of State (DoS), military leaders from the U.S. DoD, and other important U.S. representatives visited the President of Lithuania. Aside from these visits, only a Speaker of the Seimas (Parliament of Lithuania) and a Prime Minister were able to meet the U.S. President in the early 1990's. No other Lithuanian official engagements with the U.S. President were identified within the analysis. 
Table 3. Lithuanian-U.S. Presidents' and establishments' meetings where defense cooperation topics were discussed

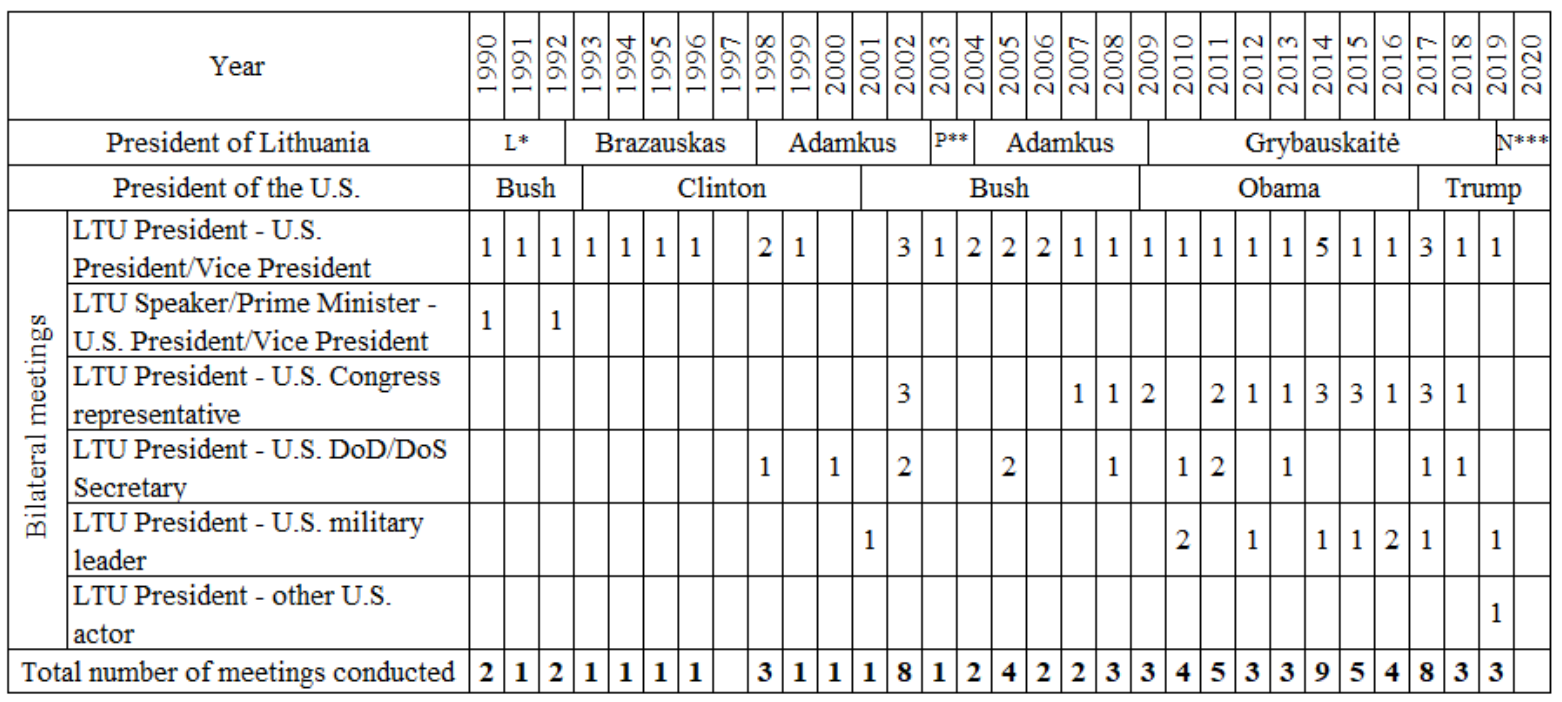

* - Vytautas Lansbergis - the Chairman of the Supreme Council of Lithuania. At that time it was the highest post in Lithuania. The President's post was established after the State Constitution was adopted on 25 October 1992.

** - President Rolandas Paksas was impeached and removed from power. Temporary replaced by Artūras Paulauskas.

**** - President Gitanas Nausèda.

The most intensive leaders' bilateral engagements happened in 2002, 2014, and 2017. In 2002, most of the decisions were made to invite Lithuania to start negotiations that would lead towards joining NATO (Figure 2). In 2014, more intensive meetings were held to emphasize that the Russian annexation of Crimea in the Ukraine could also turn out to be a threat towards the security of the Baltic countries. Therefore, active engagements at the Presidential and other levels were aiming to ensure there was political and military support primarily from the U.S. (LRP, 2014a; 2014b; 2017c). In 2017, intensive collaboration was held to discuss Russian/Belorussian military exercise 'Zapad' which was conducted near Lithuanian borders. 'Zapad 2017' exercises were treated as an expression of conventional threat against Lithuanian existence (LRP, 2017b; 2017c).

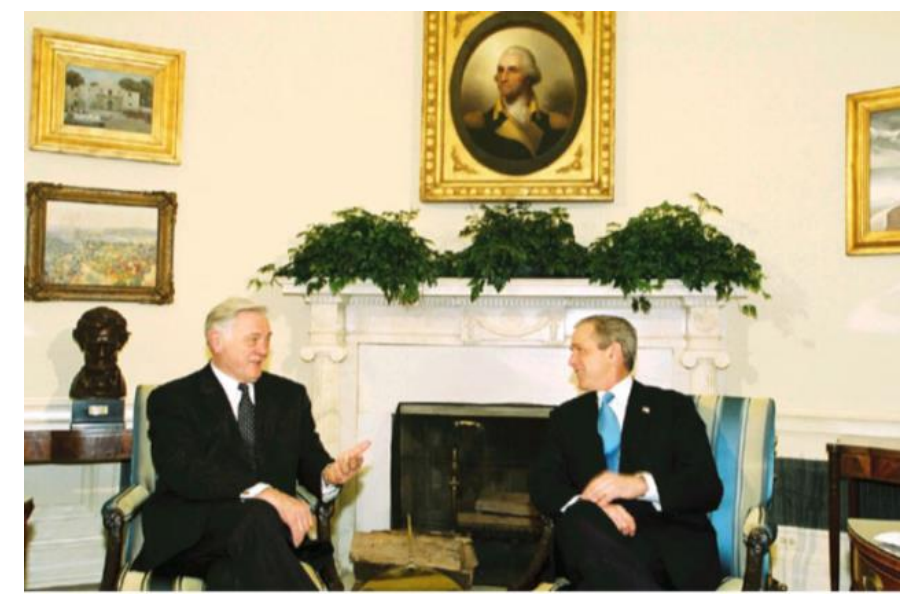

Figure 2. Lithuanian President Valdas Adamkus ${ }^{i}$ meets with the U.S. President George Walker Bush on January 17, 2002 in the White House, Washington D.C. (LRP, 2002) 
Defense topics were on the leaders' agenda in most of the meetings. Content analysis of participant speeches, meeting summaries, and official statements led to the identification of dynamics in a defense cooperation venue (Table 4).

Table 4. Generalized venues of bilateral defense cooperation from national perspectives, as discussed during various Head of States' meetings

\begin{tabular}{|c|c|c|c|c|c|c|c|c|c|c|c|c|c|c|c|c|c|c|c|c|c|c|c|c|c|c|c|}
\hline \multicolumn{2}{|r|}{ Defense cooperation venues } & \multicolumn{4}{|c|}{ 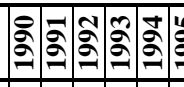 } & \multicolumn{2}{|c|}{2} & \multicolumn{2}{|c|}{20} & טి: & \multicolumn{2}{|c|}{ 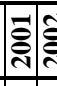 } & స్తి & 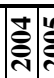 & & 紊 & \multicolumn{2}{|c|}{ 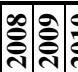 } & : & \multicolumn{2}{|c|}{ 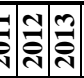 } & \multirow{2}{*}{\multicolumn{2}{|c|}{$\frac{\pi}{2}$}} & & \multirow[t]{2}{*}{ 今a } & \multirow{2}{*}{\multicolumn{2}{|c|}{ : }} \\
\hline \multirow{10}{*}{ 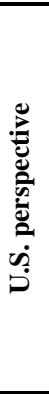 } & Medical assistance & $\bullet$ & $\bullet$ & & & & & & & & & & & & & & & & & & & & & & & & \\
\hline & USSR army withdrawal & & $\bullet$ & $\bullet$ & & & & & & & & & & & & & & & & & & & & & & & \\
\hline & PfP & & & & - & - & - & - & & - & & & & & & & & & & & & & & & & & \\
\hline & Baltic Battalion project & & & & - & - & - & - & & & & & & & & & & & & & & & & & & & \\
\hline & NATO membership & & & & & $\bullet$ & - & - & $\bullet$ & $\bullet$ & $\bullet$ & - & - & & & & & & & & & & & & & & \\
\hline & International missions led by the U.S. & & & & & & $\bullet$ & $\bullet$ & & $\bullet$ & & $\bullet$ & $\bullet$ & - & & $\bullet$ & $\bullet$ & - & - & • & $\bullet$ & - & & & & & \\
\hline & Support for military reforms & & & & & & & & & & & $\bullet$ & & & & & & & & & & & & - & & & \\
\hline & Baltic air policing and air defense & & & & & & & & & & & & & & & & & & & - & & & & - & & $\bullet$ & \\
\hline & Deterrence in the Baltic States & & & & & & & & & & & & & & & & & & & $\bullet$ & & - & $\bullet$ & $\bullet$ & - & & - \\
\hline & Acquisition of armaments & & & & & & & & & & & & & & & & & & & & & & & & & & $\bullet$ \\
\hline \multirow{13}{*}{ 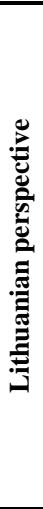 } & International/NATO military exercises & & & & & & & & & $\bullet$ & $\bullet$ & & & & & & & & & - & $\bullet$ & $\bullet$ & - & - & - & & $\bullet$ \\
\hline & NATO membership & & & & & & & & & & - & - & - & & & & & & & & & & & & & & \\
\hline & PaNG & & & & & & & & & & - & $\bullet$ & & & & & & & & & & & & & & & • \\
\hline & Modernization of LAF & & & & & & & & & & & $\bullet$ & & & & & & & & & & - & & - & & • & \\
\hline & International operations & & & & & & & & & & & & - & & s & & & - & & • & $\bullet$ & & & & & $\bullet$ & \\
\hline & Russian threat question & & & & & & & & & & & & & & & & & & & $\cdot$ & $\bullet$ & & & & $\bullet$ & & \\
\hline & Baltic air policing and air defense & & & & & & & & & & & & & & (c) & & - & & & $\bullet$ & $\bullet$ & $\bullet$ & & - & $\bullet$ & & \\
\hline & Contingency defense plans (NATO) & & & & & & & & & & & & & & & & & & & $\cdot$ & $\bullet$ & $\bullet$ & & $\bullet$ & $\bullet$ & $\bullet$ & \\
\hline & Cybersecurity & & & & & & & & & & & & & & & & & & & 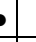 & & $\bullet$ & & & & - & \\
\hline & Lithuanian Energy Security Center & & & & & & & & & & & & & & & & & & & $\cdot$ & $\bullet$ & & & & & & \\
\hline & NATO/US troops presence in Lithuania & & & & & & & & & & & & & & & & & & & & & $\bullet$ & & - & - & & \\
\hline & Defense spending and procurement & & & & & & & & & & & & & & & & & & & & & $\bullet$ & & $\bullet$ & & & - \\
\hline & Countering hybrid warfare & & & & & & & & & & & & & & & & & & & & & & & $\bullet$ & & $\bullet$ & \\
\hline
\end{tabular}

During the meetings the U.S. representatives mentioned the following defense cooperation venues concerning Lithuania: 1) PfP project; 2) support for NATO membership; and 3) participation in international missions and deterrence operations in the Baltic States. International missions was the primary topic on the agendas at bilateral meetings leading to more than 15 years of consistent cooperation. Before joining NATO, Lithuanian interests in defense cooperation were focused on attaining NATO membership, participation in/organizing international exercises, cooperation with the Pennsylvania National Guard (PaNG), and modernization of the LAF. After joining NATO, the scope of topics related to defense cooperation was relevant to the security situation in the Baltic region. The most important defense cooperation venues that required U.S. support were as follows: 1) the U.S. troops participation in the exercises conducted in Lithuania; 2) the U.S. and NATO troops presence in Lithuania; 3) support for or participation by Lithuanian troops in international missions; 4) extension of the Baltic air policing mission and arrangements for air defense; 5) ensuring defense plans for Lithuania were prepared by NATO; and 6) defense spending and 
possible procurement. The majority of defense cooperation venues from both sides were of common interest. Some of the topics raised by the Lithuanian side, such as the Membership Action Plan to Georgia and Ukraine, did not become of particular bilateral interest.

To conclude, the importance of defense cooperation is recognized starting at the Presidents' level which is why it was often included in the agendas at bilateral meetings. The topics of bilateral defense cooperation were significantly relevant for national interests and the global security situation. The intensiveness of engagements at Presidential levels was demonstrated the relevant to Lithuanian, the Baltic States, and Poland Presidents' initiative.

\subsection{Main topics of bilateral cooperation at the Defense Minister/Secretary level}

Official ministerial meetings between the U.S. and Lithuanian defense establishments (Table 5) started after the Russian Armed Forces were withdrawn from Lithuania (Stankevičius, 1996). Within the years, Lithuanian Minister of Defense and the U.S. Secretary of Defense were able to maintain a similar frequency of meetings. However, with consideration to Lithuanian Minister's of Defense and other U.S. representatives meetings', three peak periods could be identified: 1) post-Georgian war period (2009-2010); 2) postUkrainian crisis period (2013-2015); and 3) 'Zapad 2017' and post 'Zapad 2017' periods (2017-2019).

Table 5. Meetings by Lithuanian Minister of Defense and the U.S. Secretary of Defense where bilateral defense cooperation topics were discussed

\begin{tabular}{|c|c|c|c|c|c|c|c|c|c|c|c|c|c|c|c|c|c|c|c|c|c|c|c|}
\hline Year & $\stackrel{\circ}{\stackrel{一}{\circ}}$ & $\stackrel{N}{\stackrel{2}{\varrho}}$ & $\stackrel{m}{\check{\Omega}} \stackrel{\text { ¿ }}{\Omega}$ & 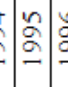 & $\stackrel{\circ}{\circ}$ & $\stackrel{\infty}{\check{\varrho}} \stackrel{\infty}{\circ}$ & 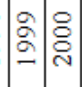 & 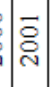 & 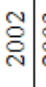 & 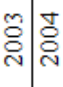 & $\stackrel{n}{\ominus}$ & $\stackrel{\circ}{\stackrel{\odot}{\odot}}$ & 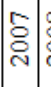 & $\stackrel{\infty}{\stackrel{\infty}{\odot}}$ & \begin{tabular}{l|l}
$\stackrel{8}{\mathrm{~S}}$ & $\stackrel{0}{\circ}$ \\
$\stackrel{\mathrm{N}}{\circ}$
\end{tabular} & 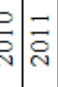 & $\stackrel{\sim}{\stackrel{N}{N}}$ & 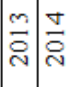 & $\frac{n}{\stackrel{N}{\circ}}$ & $\stackrel{\circ}{\circ}$ & $\stackrel{\infty}{\stackrel{N}{\circ}}$ & $\frac{a}{\grave{S}}$ & $\stackrel{\odot}{\stackrel{\mathrm{S}}{\mathrm{S}}}$ \\
\hline Lithuanian Defense Minister & \multicolumn{2}{|c|}{ Butkevičius } & \multicolumn{3}{|c|}{ Linkevičius } & \multicolumn{2}{|c|}{ Stankevičius } & \multicolumn{3}{|c|}{ Linkevičius } & $\begin{array}{c}\text { Kirki } \\
\text { as }\end{array}$ & \multicolumn{3}{|c|}{ cil Olekas } & \multicolumn{3}{|c|}{ Juknevičienẻ } & \multicolumn{3}{|c|}{ Olekas } & \multicolumn{3}{|c|}{ Karoblis } \\
\hline The U.S. Secretary of Defense & \multicolumn{2}{|c|}{ Cheney } & \multicolumn{3}{|c|}{ Perry } & \multicolumn{2}{|c|}{ Cohen } & \multicolumn{5}{|c|}{ Rumsfeld } & \multicolumn{3}{|c|}{ Gates } & \multicolumn{2}{|c|}{$\begin{array}{c}\text { Panet } \\
\text { ta }\end{array}$} & Hagel & \multicolumn{2}{|c|}{ Carter } & $\begin{array}{c}\text { Matti } \\
s\end{array}$ & \multicolumn{2}{|c|}{$* \begin{array}{c}\text { Espe } \\
\mathrm{r}\end{array}$} \\
\hline LTU Minister - U.S. Secretary & & & 1 & 1 & & 1 & 1 & 1 & 1 & 22 & 1 & 2 & 1 & 1 & 2 & 2 & 3 & 2 & 2 & & 2 & & \\
\hline $\begin{array}{l}\text { LTU Minister - U.S. Congress } \\
\text { representative }\end{array}$ & & & & & & & & & & 1 & & & & & & 1 & & 1 & 3 & 4 & 1 & 3 & \\
\hline $\begin{array}{l}\text { LTU Minister - U.S. delegation } \\
\text { from other Departments }\end{array}$ & & & 1 & 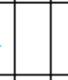 & & & & & & & & & 1 & 1 & & 3 & 1 & 2 & 1 & & 2 & 1 & \\
\hline Ministry/DoD level & & & & & 1 & & & & 2 & & 1 & 1 & 1 & & 1 & 1 & & 2 & 1 & 3 & 2 & 5 & 1 \\
\hline $\begin{array}{l}\text { LTU Minister - U.S. Military unit } \\
\text { commander/representative }\end{array}$ & & & & & 1 & & & & & 1 & & 1 & & & 2 & 3 & 2 & 5 & 2 & & 4 & 3 & \\
\hline Total number of meetings conducted & & & 2 & 1 & 2 & 1 & 1 & 1 & 3 & 2 & 2 & 4 & 3 & 2 & 5 & 2 & 6 & 811 & 9 & 7 & 911 & 12 & 1 \\
\hline
\end{tabular}

The peak engagement periods were tied to the Russian activities in Georgia, Ukraine, and military exercises 'Zapad 2017'. The exercises were conducted near Lithuanian borders and were perceived as a possible threat to Lithuanian security (LMoD, 2010b; 2014b; 2014d; LRP, 2017a). As a result, the Lithuanian defense establishment was keen to receive various 
important visitors from the U.S. and relay messages of concern. Additionally, in order to spread security-related concerns in the Baltic region to the U.S. policymakers', Lithuanian defense ministry and MoD representatives conducted engagements with the U.S Ambassador and various U.S. Think tanks (Table 6).

Table 6. Main venues of bilateral defense cooperation reflected during meetings conducted by Defense Minister/Secretary

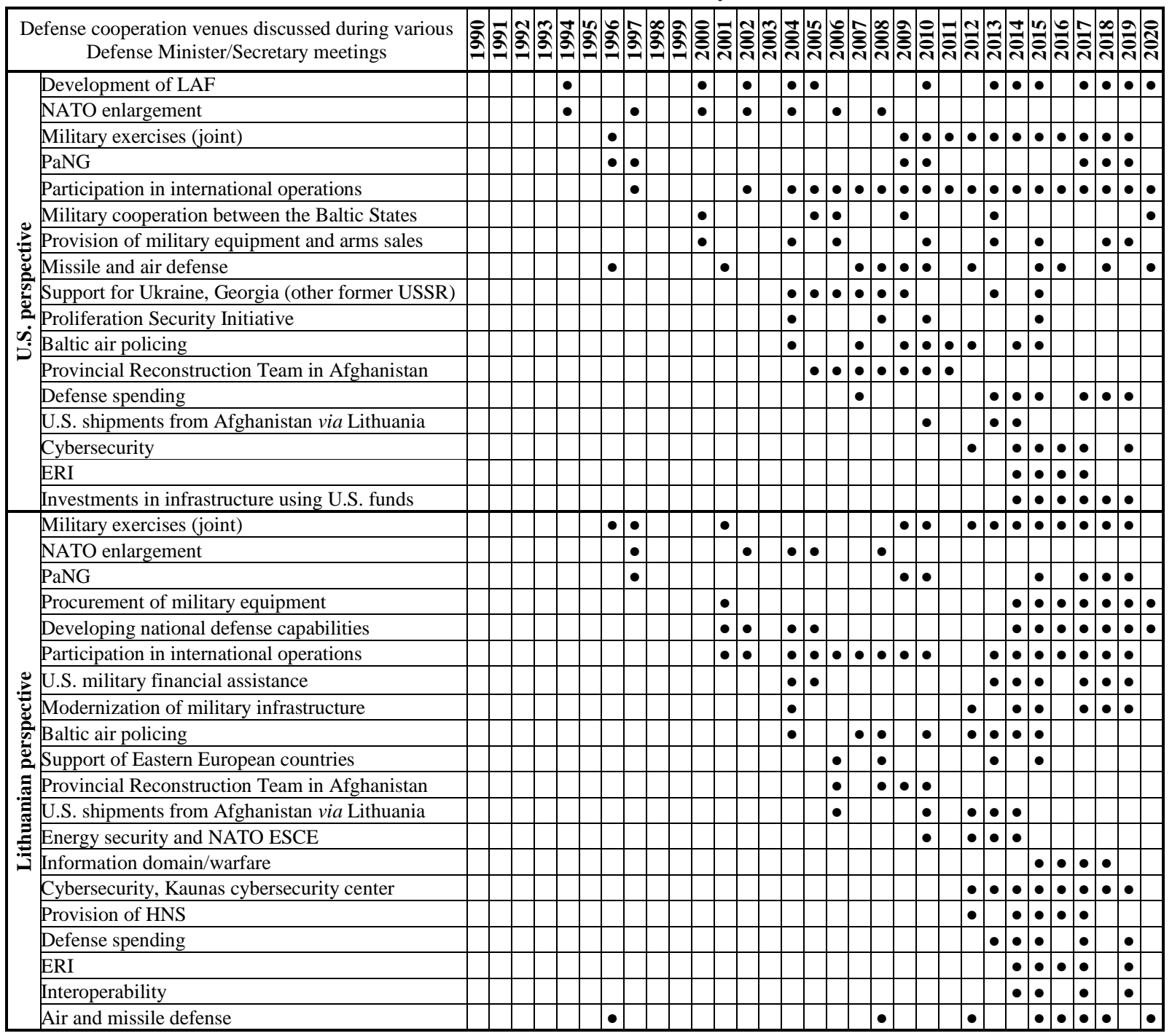

A wide spectrum of questions related to bilateral defense cooperation were discussed during meetings at the Defense Ministry/Secretarial level. The following defense cooperation venues, looking from the U.S. perspective, remained consistent throughout nearly three decades of mutual relations: support for developing the LAF; participation in international missions; the State cooperation program with PaNG; facilitation of military cooperation among three Baltic States; and a provision of military equipment and arms sales. From the Lithuanian perspective, these cooperation venues remained consistent for more than two 
decades: participation in joint exercises, development of national defense capabilities, and participation in international operations. All other cooperation venues initiated by one, or agreed upon by both, countries did not last long as they were situation driven.

From the beginning of the bilateral defense cooperation which started in 1994, the U.S. was looking to support the Lithuanian ambition to become a NATO member. After Lithuania joined NATO, the U.S. continued with its ambition to help other former USSR states to gain acceptance into NATO (until 2009) thereby using the Lithuanian platform as a means to guide Georgia and the Ukraine towards membership. Bilateral Defense Minister/Secretary meeting agendas also started including topics such as European missile defense; the Proliferation Security Initiative; support for PRT in Afghanistan; and cargo transit from Afghanistan to the U.S. via Lithuanian seaports. The following defense cooperation venues were discussed during various ministerial meetings as a result of the Ukrainian crisis: Lithuanian defense spending, Cybersecurity, ERI, and investments in Lithuanian military and civilian infrastructure. It is evident that before 2004 and the Ukrainian crisis the U.S. had limited cooperation venues with Lithuania. However, after Lithuania joined NATO, the level of cooperation greatly improved.

The focus of the Lithuanian Defense Minister and his ministerial staff meetings with the U.S. counterparts could be divided into pre- and post-Ukrainian crisis periods. Prior to 2014, the Lithuanian Defense Minister was seeking U.S. support for the acceptance of Lithuania into NATO; facilitating the NATO Baltic air policing mission; support for Lithuanian lead PRT in Afghanistan; and ways for Lithuania to assist with U.S. military cargo movement from Afghanistan to the continental U.S. via the seaport at Klaipeda, Lithuania. In the post-Ukraine crisis period, discussions mainly focused on the need for increased military cooperation as identified in messages addressed from the Lithuanian Defense Minister to various U.S. delegations. In this period, defense cooperation venues such as procurement of U.S. military equipment, provision of U.S. financial assistance, cyber security, warfare in the information domain, provision of HNS for U.S. troops, Lithuanian defense spending, interoperability between both militaries, enhancement of Lithuanian air defense capabilities, and support for implementing ERI were evident.

In summary, bilateral talks between the U.S. and Lithuanian defense establishments depended on the developments in the security domain. Having consistent meetings, as well as strict attentiveness to every detail of conversations, was critical. However, three bilateral meeting peak moments stood out as to why the state's security was a concern. The main, long-lasting defense cooperation venues of bilateral interests were identified as the 
development of and support for LAF participation in international operations. All other longlasting defense cooperation venues, such as the State cooperation program with the PaNG, arms sales, participation in joint exercises, and facilitation of military cooperation among the three Baltic States, were not equally recognized as being the most important topics for both sides. Defense cooperation venues that lasted for a shorter period were situation driven, e.g. Baltic air policing; the transit of the U.S. cargo from Afghanistan; and the implementation of ERI.

\subsection{The details of the U.S. and Lithuanian defense cooperation agreements}

There are sixteen bilateral agreements (Table 7) signed between both countries that touch on bilateral defense cooperation. The most important of them are the Memorandum on Cooperation in Defense and Military Relations, the Baltic Charter, DCA, and the Long-term Defense Cooperation Strategic Roadmap.

Table 7. The U.S. and Lithuanian agreements that include defense cooperation

\begin{tabular}{|c|c|c|}
\hline Date & Bilateral agreement & Reference \\
\hline June 10, 1992 & $\begin{array}{l}\text { Provision of Training Related to Defense Articles Under the U.S. IMET } \\
\text { Program }\end{array}$ & \multirow{5}{*}{$\begin{array}{c}\text { (DoS, 2019a; } \\
\text { Stankevičius, 1996) }\end{array}$} \\
\hline March 26, 1993 & $\begin{array}{l}\text { Grants Under the Foreign Assistance Act of 1961, as Amended, and the } \\
\text { Furnishing of Defense Articles, Related Training, or Other Defense Services } \\
\text { From the U.S. }\end{array}$ & \\
\hline January 21, 1994 & $\begin{array}{l}\text { Basic Exchange and Cooperative Agreement for Topographic Mapping, } \\
\text { Nautical and Aeronautical Charting, Geodesy and Geophysics, Digital Data } \\
\text { and Related Mapping, Charting and Geodesy Materials }\end{array}$ & \\
\hline October 28, 1994 & Memorandum on Cooperation in Defense and Military Relations & \\
\hline $\begin{array}{l}\text { November } 21, \\
1995\end{array}$ & $\begin{array}{l}\text { Treaty on Security Measures to Protect and Exchange Secret Military } \\
\text { Information }\end{array}$ & \\
\hline $\begin{array}{l}\text { April 30, } 1996 \\
\text { Updated in } 2006\end{array}$ & Agreement on Mutual Logistic Support & $(\mathrm{DoD}, 2006 \mathrm{a})$ \\
\hline \multirow{2}{*}{1997} & Cooperation Agreement Between LAF and PaNG & \multirow{2}{*}{$\begin{array}{l}\text { (KA, 2005; Radio } \\
\text { Liberty, 1997) }\end{array}$} \\
\hline & Exchange of Scientific and Technical Data in the Defense Field & \\
\hline January 16, 1998 & Baltic Charter & (DoD, 1998) \\
\hline June 11,1999 & $\begin{array}{l}\text { Basic Exchange and Cooperative Agreement Concerning Global Geospatial } \\
\text { Information and Services Cooperation }\end{array}$ & $\begin{array}{l}\text { (DoS, 2019a; LMoD, } \\
\text { 1999) }\end{array}$ \\
\hline 2002 & Agreement on the Non-Transfer of Arms to Third Countries & (Seimas, 2002c) \\
\hline $\begin{array}{l}\text { October } 10,2002 \\
\text { Updated in } 2010\end{array}$ & $\begin{array}{l}\text { The Agreement Concerning Cooperation in the Area of the Prevention of } \\
\text { Proliferation of Weapons of Mass Destruction and the Promotion of Defense } \\
\text { and Military Relations }\end{array}$ & $\begin{array}{l}\text { (Seimas, 2002a; } \\
\text { 2010) }\end{array}$ \\
\hline June 2015 & $\begin{array}{l}\text { Agreement Regarding Access To and Use of Facilities and Areas Located } \\
\text { Within Lithuania, for the Purposes of Enhanced Defense Cooperation }\end{array}$ & (DoS, 2015) \\
\hline February 14, 2017 & e & $\begin{array}{l}\text { (LMoD, 2017b; } \\
\text { Seimas, 2017b) }\end{array}$ \\
\hline April 2, 2019 & Long-term Defense Cooperation Strategic Roadmap & $\begin{array}{l}\text { (Baksa, 2019; DoS, } \\
\text { 2019b; LMoD, } \\
\text { 2019e; Mix, 2020) } \\
\end{array}$ \\
\hline
\end{tabular}

Officially, defense cooperation between Lithuania and the U.S. started in 1994 when the Memorandum on Cooperation in Defense and Military Relations was signed by the U.S. Defense Secretary, William Perry, and the Lithuanian Minister of Defense, Linas 
Linkevičius. The Memorandum specified cooperation venues that had already been foreseen in assistance for Lithuania as it joined the NATO PfP program. Furthermore, the Memorandum laid out the foundation for bilateral meetings made up of smaller working groups. The Baltic Charter, signifying enhanced partnership, envisioned several elements of defense cooperation which included: running the Baltic Peacekeeping Battalion, the Baltic Squadron, and the Baltic airspace management regime, establishment of the Baltic Security Assistance Group and establishment of the Bilateral Working Group on Defense and Military Relations.

The DCA signed in 2017 changed the Agreement regarding access to and use of facilities and the Agreement on Promotion of Defense and Military Relations. The DCA provides the necessary legal framework for the U.S. Forces' presence in Lithuania, enables U.S. military mobility, ensures access to military facilities and locations (Figure 3), and influences developments of the military infrastructure in Lithuania. This Agreement is valid for 10 years.

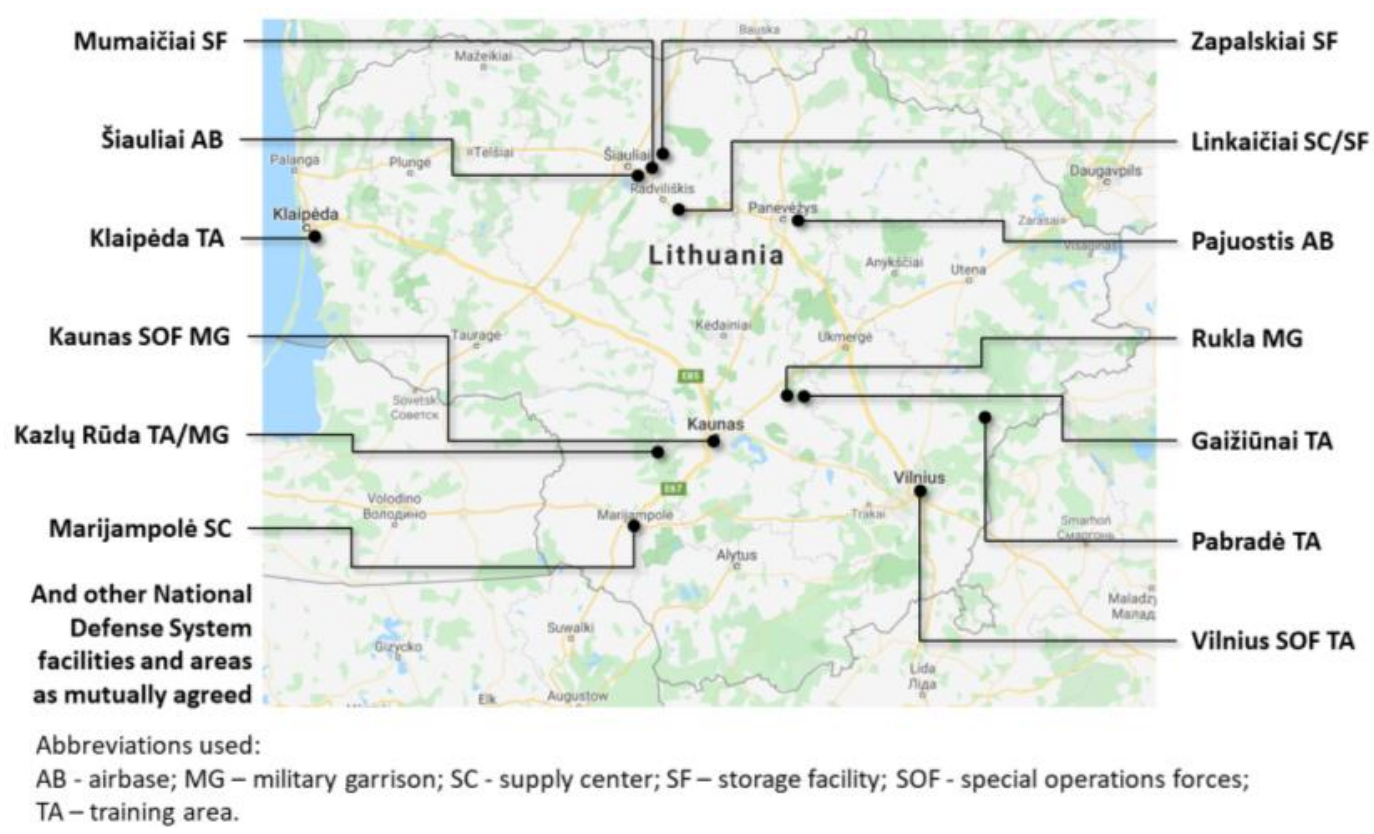

Figure 3. Lithuanian military infrastructure available for the U.S. troops (Seimas, 2017b)

The long term Defense Cooperation Strategic Roadmap signed in 2019 was the last cornerstone in bilateral cooperation. The Roadmap defines defense cooperation priorities for 2019-2024 in areas such as the improvement of defense capabilities, intelligence sharing, surveillance, cyber security, joint exercises, and training (Table 8). The Roadmap was developed to ensure continuity and appropriate financing for long term projects. The specific details of the Roadmap could be reviewed and updated annually. 
Table 8. Bilateral U.S. and Lithuanian defense cooperation venues addressed in the Defense Cooperation Strategic Roadmap for 2019-2024 (DoD, 2019; Svan \& Vandiver, 2019)

\begin{tabular}{|c|c|c|}
\hline \multicolumn{2}{|c|}{ Defense cooperation venues } & Continuous U.S. force deployments \\
\hline Defense cooperation with NATO allies & Defense cooperation with Finland and Sweden & Exchange programs \\
\hline Support in developing national defense & Provision of HNS for U.S. troops & Cooperation in multinational operations \\
\hline $\begin{array}{c}\text { Examination of command, control, } \\
\text { communication, and computers architecture } \\
\text { and standardization }\end{array}$ & $\begin{array}{c}\text { U.S. funds to complement Lithuanian national } \\
\text { funds to build anti-tank, air defense, } \\
\text { intelligence, surveillance, target acquisition, and } \\
\text { reconnaissance capabilities }\end{array}$ & $\begin{array}{c}\text { Support in replacing Soviet/Russian-made } \\
\text { equipment and platforms }\end{array}$ \\
\hline Support in maritime domain awareness & Building up cybersecurity systems & Intelligence sharing in the region \\
\hline $\begin{array}{c}\text { Improvement of Early Warning capabilities } \\
\text { support for regional integration while } \\
\text { procuring similar warfighting systems }\end{array}$ & $\begin{array}{c}\text { Developing regional approaches to security } \\
\text { Support for procurement of integrated air and } \\
\text { missile defense systems }\end{array}$ & $\begin{array}{c}\text { Working with Estonian, Latvian, and Polish } \\
\text { counterparts }\end{array}$ \\
\hline Combined exercises & Sharing lessons learned & procurement of capabilities to \\
\hline Investment in military infrastructure & Expansion of the U.S. training missions & Deterrence operations in the Baltic Sea \\
\hline
\end{tabular}

There were plenty of technical agreements signed between the U.S. DoS and Lithuanian MoD concerning exercises and small projects such as cooperation to destroy unused ammunitions and explosives (LMoD, 2011b). As technical agreements specify arrangement details for already agreed upon cooperation venues, their specifics were never further analyzed and therefore considered.

The most important agreement that set the extensive framework and clear procedures for implementing bilateral projects is DCA which was ratified by the Lithuanian Parliament on February 14, 2017. All other valid agreements have been flexible in order to accommodate new venues of defense cooperation development. The Defense Cooperation Strategic Roadmap highlights particular venues of bilateral defense cooperation from 2019-2024. The Roadmap indicates priorities and is scripted to ensure there is continuity and proper financing of long-term projects.

\subsection{Are the U.S. and Lithuanian defense cooperation interests aligned?}

Three decades of bilateral cooperation in the military field between the U.S. and Lithuania have been intensive with periods of leadership engagements. The first period of enhanced bilateral cooperation with an abundance of activities in the defense field and more frequent leadership engagements at Presidents' and Defense Minister/Secretary's levels occurred from 1998-2004, in the pre-NATO membership period. The second period took place from 2014-2018 and reflected on a post-Ukraine crisis when Lithuania also felt threatened by Russia. During both periods, the topic of defense cooperation was clearly on the meeting agendas at many levels including those of many political leaders and executive ministerial levels, while ultimately being written into the training scenarios for many military units and agencies involved in making the cooperation a reality. Additionally, multiple 
bilateral agreements were signed, while updates in the U.S. and Lithuanian strategic documents related to state security and defense went into effect in order to start putting leaders' agreements into practice.

A comparison of outcomes following Presidential and Defense Minister/Secretary speeches and meetings (Table 4 and Table 6) seem to indicate that the Defense Minister/Secretary agendas covered a wider array of topics as compared to the President agendas, possibly also giving a comparison of levels of competency. Some topics discussed at both levels stressed continuity whereas other topics sought only to meet short term goals. Moreover, some of the messages were not equally emphasized during engagements at various levels, e.g. the Lithuanian President described the Zapad 2017 exercise as an existential threat for Lithuanian security in the post-2014 period, while the Defense Minister did not touch on the potential impact of Zapad 2017 at all.

The comparative analysis of the long term Defense Cooperation Strategic Roadmap for 2019-2024 and the Leaders' discussed/agreed upon cooperation venues during 2018-2020 meetings (Table $8 v s$ Table 4 and Table 6) show that out of 27 venues included in the Roadmap, defense cooperation was mentioned in only 16 Leader's meetings. The other 11 venues in the Roadmap touched on defense cooperation in other aspects, e.g. defense cooperation in regards to Finland and Sweden, the sharing of lessons learned, and support during maritime domain awareness.

While considering strategic, DoD/MoD documents, speeches, meeting summaries, and Agreements, the most important and lasting venues of bilateral cooperation identified during content analysis remain the same, 1) participation in the international operations, 2) increasing LAF capabilities, and 3) having U.S. military presence in Europe and the Baltic region. The armament procurement/LAF modernization topic was one of the venues of bilateral interest, however, its validity was quite short before entering NATO and during the period of 2014-2020. The DCA and Defense Cooperation Strategic Roadmap highlight that armament acquisition is a topic pertaining to the U.S. that must continue to be exploited. This reason is because the U.S. only has the capability to provide defense articles at a sufficient price that will still allow it also cover all included expenses as in some observed cases. 


\section{Specifics of Armament Procurement from the U.S.}

\subsection{Lithuanian defense budget and armament procurements from the U.S.}

Over the last 30 years, Lithuania had rises and drops in its defense spending (Table 9). The fluctuation resulted from the economic situation, the political will, security situation at any given time, and the need to allocate various percentages of funding to meet defense needs, and meet the criteria to join NATO.

Table 9. Lithuanian defense spending during 1990-2020 (LMoD, 2005; 2009b; 2020; SIPRI, 2019)

\begin{tabular}{|c|c|c|c|c|c|c|c|c|c|c|c|c|c|c|c|c|c|c|c|c|c|}
\hline Defense spending & 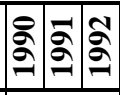 & $\approx$ & בิे & 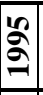 & ڤั้ & 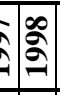 & 2 & స్తి & ฮิి & & ֻิి & Ð્ণ & & 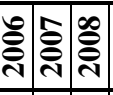 & ) & & 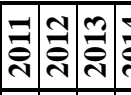 & 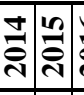 & |⿳亠幺𠃌亍 & $\mid \frac{\pi}{\stackrel{4}{a}}$ & \\
\hline MoD budget*, million Euro & n.d. & ¿.: & 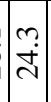 & m. & \begin{tabular}{l|l}
0 & 0 \\
$\dot{y}$ & $\infty$
\end{tabular} & \begin{tabular}{ll|l}
0 & 0 \\
0 & 0 \\
0 & 0 \\
0
\end{tabular} & $\begin{array}{l}m \\
\text { ñ } \\
\end{array}$ & $\begin{array}{l}0 \\
i \\
\text { i }\end{array}$ & ma & 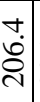 & $\begin{array}{l}r \\
\hat{n} \\
\text { ते }\end{array}$ & \begin{tabular}{l}
$a$ \\
$\infty$ \\
\multirow{2}{\Delta}{}
\end{tabular} & ت্ & 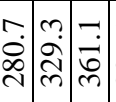 & 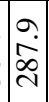 & 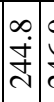 & 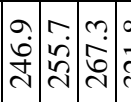 & 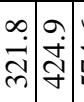 & \begin{tabular}{ll}
0 & $\infty$ \\
\multirow{1}{*}{} & $\stackrel{n}{N}$ \\
in
\end{tabular} & 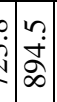 & 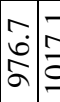 \\
\hline $\begin{array}{l}\text { MoD budget, \% of Gross } \\
\text { Domestic Product (GDP) }\end{array}$ & n.d. & 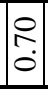 & $\stackrel{\infty}{\infty}$ & 光 & $\hat{n}$ & 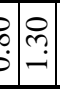 & $-\frac{1}{0}$ & $\stackrel{m}{m}$ & $\stackrel{q}{q}$ & 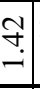 & 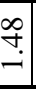 & $\stackrel{f}{\ominus}$ & & \begin{tabular}{l|l|l|l|}
$\infty$ & $\infty$ & $\infty$ \\
\hdashline & $\sim$ & - & - \\
\end{tabular} & 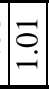 & $\begin{array}{ccc}\infty & \\
\infty & 1 \\
\circ & 5 & 5 \\
\end{array}$ & \begin{tabular}{|l|l|l|l}
$\infty$ & $\infty$ & 1 & 0 \\
0 & 0 & 0 & 0 \\
0 & 0 & 0 \\
\end{tabular} & 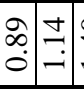 & 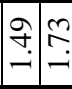 & $\stackrel{\infty}{\infty}$ & \\
\hline $\begin{array}{l}\text { Overall defense spending**, } \\
\% \text { of GDP }\end{array}$ & & & n.d. & & & & \pm & I. & 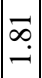 & ஓ & 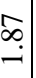 & ஓे & g. & & & & n.d. & & & & \\
\hline
\end{tabular}

During the period 1999-2005, Lithuanian spending for national defense was understood and calculated differently. Previously, the defense budget included expenses related to national security programs or projects implemented through different ministries in coordination with MoD. Examples of this included the 1st and 2nd Regiments of Ministry of Inner Affairs (the guarding of prisons and efforts to ensure public order was maintained) and counter-terrorism programs run by the Police Department (LMoD, 2005).

The increase of defense spending in the last decade allowed for the possibility to implement necessary reforms in the defense structure, and to plan and start acquiring defense articles required for LAF. Cooperation with the U.S. in the defense field included arms acquisition (Annex 1), where the U.S. DoD/DoS donated some equipment, or else they contributed to the procurement by means of covering a percentage of the overall cost. Within the period of 2016-2020, Lithuania spent approximately 20 percent of its defense budget to acquire new modern armaments and military equipment, of which more than half was imported from the U.S. The latest procurements from the U.S. has included 'UH-60M Black Hawk' helicopters and 'L-ATV Oshkosh' armored all-terrain vehicles (Figure 4). These purchases have illustrated Lithuania's commitment towards strengthening its defense and its desire for greater interoperability with U.S. Forces. Part of the reason the U.S. was willing to cover some of the costs for the procurements was its desire to LAF increase its defense 
capabilities. For example, the U.S. contributed 27 million Euro for the latest procurement of six utility helicopters, and another 4.5 million Euro for a 'Jewelin' anti-tank system. The latest U.S. program, ERI, allowed Lithuania to build up ammunition stocks, and to acquire one de-icing vehicle for $\mathrm{C} 17$ airplanes, tactical radios, and anti-UAV equipment. The Latest figures show that the U.S. provided over 27 million Euros worth of support to Lithuania through ERI within 2015-2016 and over 90 million Euros for the Baltic States to build its ammunition stockpile in 2018 (Global Security, 2015; Howard, 2018; LMoD, 2019b; Metha, 2020; WH, 2016).
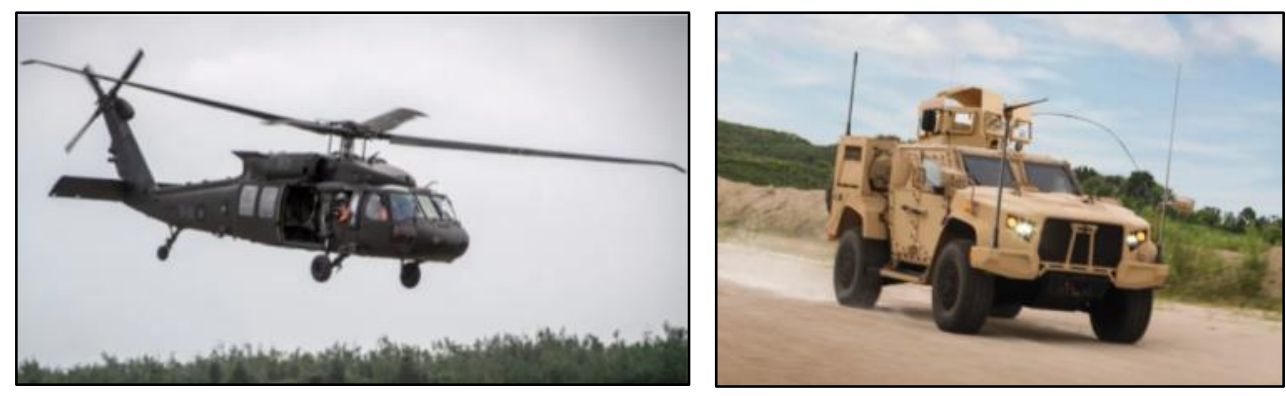

Figure 4. The 'UH-60M Black Hawk' helicopter (left) and the 'L-ATV Oshkosh' armored all-terrain vehicle (right) (Pictures obtained from defpost.com)

There are random speculations rather than actual statements by military leaders regarding future armament procurements for LAF. The Development Program of LNDS for 2019-2028 provides vague expectations regarding the force capability in the foreseeable future. The development program that is in line with LNSS highlights capabilities that should be developed in the short term outlook (Seimas, 2018). The more precise arrangements for future military equipment and armaments should be available in due time in the MoD Guidelines and the MoD Plan. In the near future, it is expected that Lithuania will spend no less than 221 million Euros annually for acquiring new defense articles and refurbishing the old ones. The comparison of the Development Program of LNDS and Defense Cooperation Strategic Roadmap for 2019-2024 (Table 8) initially indicated that some of the future armaments could come from the U.S. because the U.S. DoD/DoS is ready to commit funds to support future Lithuanian defense developments by means of procurement of anti-tank weaponry, and enhancement of intelligence, surveillance, target acquisition, and reconnaissance capabilities. Secondly, the U.S. DoD/DoS is ready to support the Baltic States with changing out their current Soviet/Russian-made equipment with similar warfighting systems. The recent U.S. National Defense Authorization Act for Fiscal Year 2020 (No 11692) indicates that the security assistance package to the Baltic States in 2021 will increase up 
to 125 million USD for the various activities that are already in place per the Defense Cooperation Strategic Roadmap. Additionally, the Committee of Appropriations report (No 116-103) for the Senate recommends an allocation of 400 million USD for the Defense Security Cooperation Agency (DSCA) to fund an air defense radar system in the Baltic region (Mix, 2020).

During the existence of LAF, there have been two periods, 2004-2005 and 20182020, when defense spending was maintained at the 2 percent GDP level. The first period was related to Lithuania becoming a NATO member, and the second one was due to the need for LAF to gain reinforcements due to arising threats. The increase of defense spending for armament procurements positively impacted LAF. The U.S. remains to not only be the primary weapons and ammunition supplier for Lithuania, but it is also the main reliable ally assisting the LAF with the necessary funding to maintain this capability. Upcoming future arms procurement activities between the U.S. and Lithuania could be of great value as it would allow the LAF to further improve its strength and capabilities through 2028 and also add to the interoperability of U.S. and Lithuanian Forces for the foreseeable future. As the U.S. continues its support, it is important for those individuals involved to continue to learn about the U.S. arms sales programs to that Lithuania can continue to take advantage of the most prospective opportunities.

\subsection{Lithuanian options to acquire arms from the U.S.}

The arms acquisition process in Lithuania is slow and steady, but it is the way so that the process remains 'transparent' for the taxpayers who have invested their money towards the defense of the country. The first step in the process is the approval of the Development Priorities of the LNDS by Seimas. Within this step is also the responsibility of the MoD to provide more specific descriptions of the mentioned capabilities which must then be approved by the Government and the Committee on the National Security and Defense in Seimas. The second step is for the LAF to determine technical requirements and specifications with the support of experts who conduct optional testing. Once requirements for future acquisition are known and the budget is prepared, the procurement takes place. The procurement process related to arms acquisition is normally run by the Defense Material Agency of the MoD which is responsible for centralized procurements. Based on EU laws and national regulations, the Lithuanian MoD can choose multiple ways to proceed with the procurement process. The MoD can follow Procurement Law in the defense field, can use an 
exclusion to the Procurement Law which is that it can use an international agency to support procurement, i.e. the NATO Support and Procurement Agency, simply initiate procurement based on a government-to-government (G2G) agreement (Palavenis, 2020). A G2G agreement adds more transparency to procurement. An example of this is how in the U.S., all weapons sales need to be approved by different layers of Executive power and Congress has to notified.

Armament procurements from the U.S. are based on the G2G agreement, with the same procedure having being applied during the latest LAF procurement of 'L-ATV Oshkosh' armored all-terrain vehicles and 'UH-60M Black Hawk' helicopters (Beniusis, 2020; LMoD, 2019f). Procurement of 'new,' ‘used,' or 'excessive' U.S. armaments could be accomplished by means of Foreign Military Sales (FMS) or Direct Commercial Sales (DCS) (DoS, 2020b).

FMSs are conducted by DSCA through negotiations with U.S. Defense contractors who also provide user training, maintenance training, and contracting logistical support. DSCA charges foreign buyers a 3.2 percent administrative fee and 1.2 percent FMS contract administrative services fee based on the total cost of each sale. The FMS process begins with a country submitting a formal Letter of Request that specifies the expected military capability. In most cases, foreign sales are approved by DoS and followed up with notification to Congress. Once Congress is notified, the DSCA informs the country procuring the product by means of a Letter of Offer and Acceptance that covers all the details of the sale. If the purchasing country accepts all proposed conditions, a contract is signed by both parties involved (DoS, 2020b; DSCA, 2014; 2018; 2020b).

When conducting DCS transactions, foreign governments negotiate directly with the respective U.S. companies. In FMS and DCS situations, export licenses must be approved by the Directorate of Defense Trade Controls at the DoS. If FMF is provided by the U.S. government to support the purchase of the U.S. defense articles or services thru various programs such as ERI or the European Recapitalization Incentive Program, then the procurement process is being conducted using FMS (DoS, 2020a; 2020b).

When excess defense equipment are purchased at a reduced price (ranging from 5-50 percent of the original purchase value), approval must be received form the DoS and Congress must be notified. The DSCA facilitates the process for the transfer of excess defense articles to other countries when the transaction is conducted using either FMS or be supported from a grant. However, Lithuania has not used these methods in the last few 
decades, whereas other NATO countries similar in size, i.e. Albania, Croatia, Estonia, and Slovenia have used them extensively (DoS, 2020b; DSCA, 2020a).

To reemphasize, Lithuania strives to keep the lengthy armament procurement process as transparent as possible for the public. While acquiring defense articles from the U.S, a G2G agreement allows the purchaser to pay an optimal price, to get expert advice, and to get the support available from the DSCA. Other available options for acquiring U.S. excess defense articles are not used yet by Lithuania.

\subsection{Considerations for retrospective and future arms acquisitions from the U.S.}

Since other NATO countries are using U.S. equipment acquired using similar programs, an analysis could help to determine if the U.S. defense policymakers in the DoD/DoS are applying similar purchase conditions for various customer countries. One such comparative analysis which was conducted shows why Lithuania opted to procure 'L-ATV Oshkosh' armored all-terrain vehicles and 'UH-60M Black Hawk' helicopters from the U.S. using the support of the DSCA (Table 10).

Table 10. Helicopter 'UH-60M Black Hawk' and armored vehicle 'L-ATV Oshkosh' procurement comparison by different NATO countries (DSCA, 2020c; 2020d)

\begin{tabular}{|c|c|c|c|c|c|}
\hline \multicolumn{6}{|c|}{ Helicopter 'UH-60M Black Hawk' } \\
\hline Country & Croatia & Czech Republic & Latvia & Lithuania & Slovakia \\
\hline Amount procured, unit & 2 & 12 & 4 & 6 & 9 \\
\hline Estimated cost per unit, million USD & 57.5 & 66.7 & 50 & 63.3 & 50 \\
\hline \multicolumn{6}{|c|}{ Armored Vehicle 'L-ATV Oshkosh' } \\
\hline Country & \multicolumn{3}{|c|}{\begin{tabular}{c|} 
Lithuania \\
\end{tabular}} & \multicolumn{2}{|c|}{ United Kingdom } \\
\hline Amount procured, unit & \multicolumn{3}{|c|}{200} & \multicolumn{2}{|c|}{2,747} \\
\hline Total cost, million USD & \multicolumn{3}{|c|}{170.8} & \multicolumn{2}{|c|}{1,035} \\
\hline Estimated cost per unit, million USD & \multicolumn{3}{|c|}{0.85} & \multicolumn{2}{|c|}{0.37} \\
\hline
\end{tabular}

The latest procurements of 'UH-60M Black Hawk' from the U.S. were carried out by five small NATO countries. Unfortunately, each procurement per country consisted of different helicopter modifications, different quantities purchased, different training programs, and different spare part sets purchased making a comparison nearly impossible. Prices per unit differed within a 33 percent margin at costs from 50 million up to 66.7 million USD. It is also interesting to note that the U.S. DoD paid approximately 15 million USD per unit for the same helicopter configuration in 2017 (Adams, 2017). The procurement prices of the vehicle 'Oshkosh' for Lithuania and the U.K. varied because different quantities were purchased. The approximate price per unit for the U.S. DoD was 0.25 million USD (Barrett, 2019). Here again, U.S. companies sold the same defense item at different prices because the quantities 
and modifications requested were also different. There were however no findings to show that the policies used to offset the prices of the procurements were different for each country.

A review of the procurements by Estonia, Latvia, and Lithuania from 1990-2020 showed they each acquired varying quantities of defense equipment from the U.S. (Table 11 and Annex 2), although the U.S. policies for the transactions with each country were similar.

Table 11. Agreements signed by the Baltic States to acquire major defense items from the U.S. during 1990-2020

\begin{tabular}{|c|c|c|c|c|c|c|c|c|c|c|c|c|c|c|c|c|c|c|c|c|c|c|c|c|c|}
\hline $\begin{array}{c}\text { Number of armaments } \\
\text { agreements }\end{array}$ & ڤิ & $\bar{\partial}$ & & 2 & & & ڤે & $\stackrel{2}{\approx}$ & & ఫิ & ฮิ & 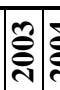 & હ઼્ે & 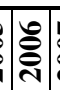 & ટ્ને & & ) & $\overline{\bar{z}} \mid \mathfrak{d}$ & 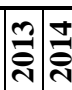 & $\frac{\sqrt{4}}{2}$ & & & בิ่ & 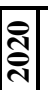 & 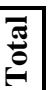 \\
\hline Estonia & & & & & & & 1 & & & 2 & & & & & & & & & \begin{tabular}{|l|l|} 
& 1 \\
\end{tabular} & 1 & & \begin{tabular}{l|l}
1 & \\
\end{tabular} & & & 5 \\
\hline Latvia & & & & & & & & & & 1 & & & & & 1 & & 2 & & & 2 & & 1 & & & 7 \\
\hline Lithuania & & & & & & & & & & 1 & 2 & & 1 & 1 & & & & 1 & & & 2 & 1 & 1 & \begin{tabular}{|l|l|}
1 \\
\end{tabular} & 11 \\
\hline
\end{tabular}

The review showed several interesting points such as that Lithuania had procured the most number of armaments from the U.S., and four specific defense articles were acquired by more than one of the countries, but they were purchased in different years. When comparing the prices that each country paid to procure their defense items, (Annex 2), one could conclude that the U.S. sets the Baltic States in a single construct pricing range. These types of construct pricing strategies seem to be established for other European regions as well.

Baltic States, including Lithuania, paid little attention to the excess defense articles program proposed by the U.S. This program allows purchasing countries to take varying amounts of grants and procure defense items at a reduced prices. The latest acquisition of 'Bradley' infantry fighting vehicles by Croatia (120 units at a cost of 0.130 million USD per unit) and Greece (367 units at a cost of 0.106 million USD per unit), 'HMMWV' armored vehicles by Albania (159 units at a cost of 0.044 million USD per unit) highlights the opportunities that the excess defense articles program can provide to other countries (DSCA, 2020a). 'Bradleys' and 'HMMWVs' (Figure 5) still maintain fighting potential regardless of the production date and urgent need for modernization. How could this data relate to the current Lithuanian procurements? 'Bradleys' cost per unit without modernization and transportation expenses was 0.106-0.130 million USD as compared to a new 'Boxer' infantry fighting vehicle purchased for 4.875 million USD. The 'HMMWV' price was 0.044 million USD whereas the new 'L-ATV Oshkosh' cost 0.85 million USD. As prices differ in times, the leadership of the MoD could consider taking advantage of the U.S. excess defense articles program. 

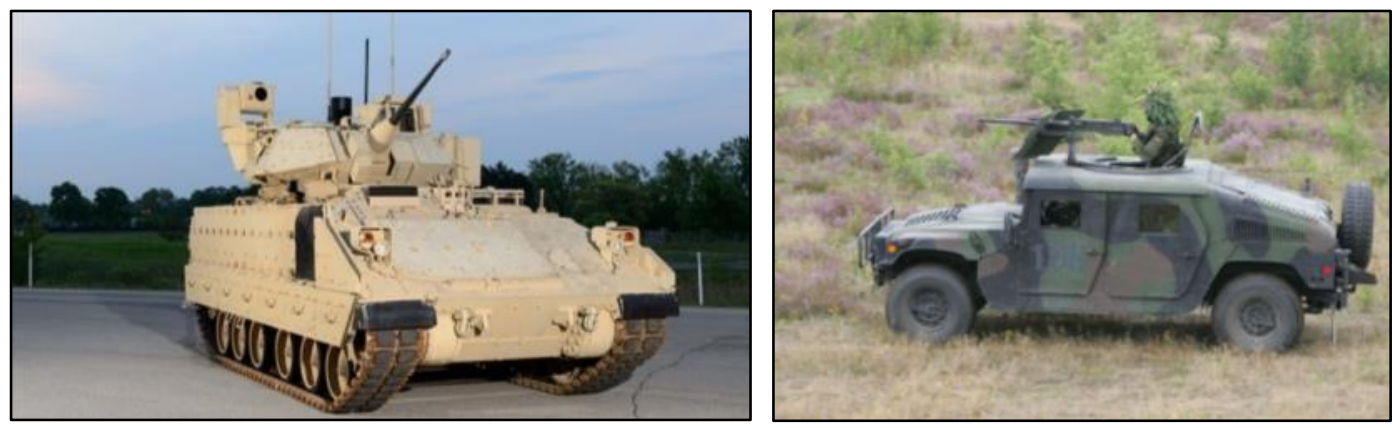

Figure 5. 'Bradley' Infantry Fighting Vehicle (left). Model M111 Armored vehicle 'HMMWV'(right). (Pictures from defpost.com)

To summarize, the pricing policies for U.S. defense articles remain similar in most cases regarding NATO countries unless the procurements are for large quantities. Lithuania is procuring the largest number of defense armament equipment from the U.S. as compared to Estonia and Latvia. However, at the most positive aspect of the scenario, the Baltic States could combine their military capabilities multilaterally which would likely result in a high level of appreciation for the availability of the U.S. defense procurement programs. Lithuania's perception of the U.S. excess defense article program is that it could still be refined so that it offers reliable equipment at a more modest price. On the other hand, the acquisition of excess defense items as such still would require technical modernization resulting in additional expenses.

\section{Conclusion}

Bilateral cooperation between the U.S. and Lithuania over the last three decades has been intense with defense cooperation being one of the topics that keeps both countries bound together. The support the U.S. provided to Lithuania during its aspiration to become a NATO member and active participant in deterrence related activities in the Baltic Sea region between 2014-2018 was well balanced with the Lithuanian political-military loyalty it has shown in return. The U.S. Department of Defense and Lithuanian Ministry of Defense documents highlight three main aspects of bilateral concerns regarding military cooperation: participation in international operations, enhancing Lithuanian Armed Forces' capabilities, and ensuring there continues to be U.S. military presence in Europe, particularly the Baltic region.

Most of the new defense cooperation initiatives started at Presidential level meetings. Bilateral talks between the U.S. and Lithuanian defense establishments have revealed that there are great advantages in further developing defense cooperation. The Defense 
Cooperation Agreement and Defense Cooperation Strategic Roadmap are the most important documents setting up the framework for cooperation and highlighting specific joint venues and ongoing projects.

Lithuania's increased defense spending from 2004-2005 and 2018-2020 reached NATO requirements of 2 percent of Gross Domestic Product which also facilitated procurements of military equipment thru U.S. government to government arrangements. This made possible the usage of the U.S. Foreign Military Support program to acquire armaments from the U.S. which additionally ensured optimal prices, better service, and greater transparency based on the involvement of the Defense Security Cooperation Agency. Research outcomes of the latest NATO countries' defense equipment procurements conducted by the Defense Security Cooperation Agency in providing similar defense articles showed that prices proposed for countries were similar with some exceptions based on varying purchase quantities and requested modifications.

Lithuania still has not sought the U.S. excess defense articles that are still in good quality and are sold at an optimal price. The analysis of recent procurements made by Albania, Croatia, and Greece reveals the potential of the program that could sought after by Lithuania in the future. The Baltic States could consider that opportunity and try to narrow the gap between individual and regional security interests by trying to procure armaments thru U.S. regional defense programs via trilateral or quadrilateral arrangements. However, proper synchronization would be required as there have not been very many combined armament procurements conducted within the Baltic States to this day to compare from.

Acknowledgements. My thanks to unknown scholars who took the time to review and evaluate the paper. I would also like to extend my warm thanks to Dr. Vaidotas Urbelis (Defense Policy Director at Lithuanian MoD), Dr. Alisa Palavenienè (Kaunas University of Technology, Lithuania) for their review remarks and advice. Special thanks to Mr. Will Gonzales (HQ MNCNE) for the English proofread.

\section{Notes}

i -Valdas Adamkus returned to Lithuania after spending nearly 50 years in the U.S. He formally gave up his U.S. citizenship before his swearing in at the office of the President. 


\section{References}

Adams, R. (2017). Sikorsky lands potential \$5B army contract for Black Hawk helicopter production. Retrieved from https://www.govconwire.com/2017/07/sikorsky-lands-potential-5b-armycontract-for-black-hawk-helicopter-production/

Baksa, B. (2019). The US and the Eastern European defence cooperation agreements: Impacts, geopolitics and the Hungarian case. Foreign Policy Review, , 112.

Baltictimes. (2019). Lithuanian army signs preliminary EUR 8.7 mln contract on communication systems. Retrieved from https://www.baltictimes.com/lithuanian army signs preliminary eur $87 \mathrm{mln}$ contract on co mmunication_systems/

Barrett, R. (2019). Oshkosh Corp. receives $\$ 195$ million order for more military vehicles. Retrieved from https://eu.jsonline.com/story/money/2017/08/02/oshkosh-corp-receives-195-million-ordermore-military-vehicles/533522001/

Beniusis, V. (2020). Lietuva tikisi rugsèji pasirašyti sutartị dėl sraigtasparnių „Black hawk“. Retrieved from https://www.lrt.lt/naujienos/lietuvoje/2/1198780/lietuva-tikisi-rugseji-pasirasytisutarti-del-sraigtasparniu-black-hawk

Bush, G. (2002). National security strategy. Retrieved from https://georgewbushwhitehouse.archives.gov/nsc/nss/2002/

Bush, G. (2006). National security strategy. Retrieved from https://history.defense.gov/Portals/70/Documents/nss/nss2006.pdf?ver=2014-06-25-121325-543

Derse, A. E. (2015). The next steps in U.S.-Lithuania relations. Retrieved from http://lfpr.lt/wpcontent/uploads/2015/08/LFPR-23-Derse.pdf.

DoD. (1997). Quadrennial defense review. Retrieved from https://www.hsdl.org/?abstract\&did=719619

DoD. (1998). A charter of partnership among the United States of America and the Republic of Estonia, Republic of Latvia, and Republic of Lithuania. Retrieved from https://19972001.state.gov/www/regions/eur/ch_9801_baltic_charter.html

DoD. (2001). Quadrennial defense review. Retrieved from https://www.hsdl.org/?abstract\&did=1851

DoD. (2005). National defense strategy of the United States. Retrieved from https://www.hsdl.org/?abstract\&did=452255

DoD. (2006a). International agreement - acquisition and cross-servicing agreement (ACSA) (USALTU-02) between the Department of Defense of the United States of America and the Ministry of National Defence of the Republic of Lithuania. Retrieved from https://20092017.state.gov/documents/organization/75310.pdf

DoD. (2006b). Quadrennial defense review. Retrieved from https://history.defense.gov/Portals/70/Documents/quadrennial/QDR2006.pdf?ver=2014-06-25$111017-150$

DoD. (2008). National defense strategy of the United States. Retrieved from https://www.hsdl.org/?abstract\&did=487840

DoD. (2010). Quadrennial defense review. Retrieved from https://history.defense.gov/LinkClick.aspx?fileticket=tFG_5ZPMhBk\%3d\&tabid=9114\&portalid $=70 \& \mathrm{mid}=20230$

DoD. (2014). Quadrennial defense review. Retrieved from https://history.defense.gov/Portals/70/Documents/quadrennial/QDR2014.pdf?ver=2014-08-24$\underline{144246-293}$ 
DoD. (2018). National defense strategy of the United States. Retrieved from https://dod.defense.gov/Portals/1/Documents/pubs/2018-National-Defense-StrategySummary.pdf

DoD. (2019). U.S., Lithuania detail roadmap for cooperation through 2024. Retrieved from https://www.defense.gov/Explore/News/Article/Article/1803578/us-lithuania-detail-roadmapfor-cooperation-through-2024/

DoS. (2015). Agreement between the United States of America and Lithuania. Retrieved from https://2009-2017.state.gov/documents/organization/245239.pdf

DoS. (2019a). Treaties in force. A list of treaties and other international agreements of the United States in force on January 1, 2019. Retrieved from https://www.state.gov/wpcontent/uploads/2019/06/2019-TIF-Bilaterals-6.13.2019-web-version.pdf

DoS. (2019b). U.S. security cooperation with the Baltic States. Retrieved from https://www.state.gov/u-s-security-cooperation-with-the-baltic-states/

DoS. (2020a). Congressional budget justification Y 2021. Retrieved from https://www.state.gov/wpcontent/uploads/2020/02/FY-2021-CBJ-Final.pdf

DoS. (2020b). U.S. arms sales and defense trade. Retrieved from https://www.state.gov/u-s-armssales-and-defense-trade/

DSCA. (2014). Cost of foreign military sales reduced. Retrieved from https://dsca.mil/newsmedia/news-archive/cost-foreign-military-sales-reduced

DSCA. (2018). DSCA to reduce FMS administrative surcharge for partners. Retrieved from https://dsca.mil/news-media/news-archive/dsca-reduce-fms-administrative-surcharge-partners

DSCA. (2020a). Excess defense articles. Retrieved from https://dsca.mil/programs/excess-defensearticles-eda

DSCA. (2020b). Foreign military sales. Retrieved from https://dsca.mil/programs/foreign-militarysales-fms

DSCA. (2020c). Joint light tactical vehicles. Retrieved from https://www.dsca.mil/search/node/JOINT\%20LIGHT\%20TACTICAL\%20VEHICLES

DSCA. (2020d). Uh-60m Black Hawk helicopters. Retrieved from https://www.dsca.mil/tags/uh-60mblack-hawk-helicopters

Giuseppetti, S. (2002). Harris corporation awarded \$13.2M contract from Lithuanian ministry of defence for Falcon ${ }^{\mathrm{TM}}$ II digital radio systems. Retrieved from https://www.harris.com/pressreleases/2002/03/harris-corporation-awarded-132m-contract-from-lithuanian-ministry-ofdefence

Global Security. (2015). Lithuania-Javelin missiles and command launch units. Retrieved from https://www.globalsecurity.org/military/library/news/2015/12/mil-151218-dsca01.htm

Grina, G. (2017). Nacionalinè karinė diplomatija ir jos perspektyvos. Lietuvos Metine Strategine Apžvalga, 15, 161-182.

Howard, G. E. (2018). Enabling deterrence: U.S. Security policy toward the Baltic. Paper presented at the Security of the Baltic Sea Region Revisited Amid the Baltic Centenary, 83.

Jakštaite, G. (2011). Lithuania in US foreign policy during the presidencies of B. Clinton and B. Obama. Baltic Journal of Law \& Politics, 4(2), 187-216.

Jakštaite, G. (2014). Lietuvos užsienio politika: Santykiai su JAV. Lietuva Globalioje Erdveje: Metinė Apžvalga 2013-2014 M, , 31-37.

Jakstaite, G. (2019). The US foreign policy towards the Baltic States: The implications of Ukraine crisis. Journal on Baltic Security, 5(1), 27-39.

JCoS. (1992). The National military strategy of the United States of America 1992. Retrieved from https://history.defense.gov/LinkClick.aspx?fileticket=U2yb8zyjIIg\%3d\&tabid=9116\&portalid=7 $\underline{0 \& \operatorname{mid}=20232}$ 
JCoS. (1995). The National military strategy of the United States of America 1995. Retrieved from https://www.hsdl.org/?abstract\&did=746414

JCoS. (1997). The National military strategy of the United States of America 1997. Retrieved from https://history.defense.gov/LinkClick.aspx?fileticket=4WoTIIhAUD0\%3d\&tabid=9116\&portali $\mathrm{d}=70 \& \mathrm{mid}=20232$

JCoS. (2004). The National military strategy of the United States of America 2004. Retrieved from https://web.archive.org/web/20070509144917/http://www.defenselink.mil/news/Mar2005/d2005 0318nms.pdf

JCoS. (2011). The National military strategy of the United States of America 2011. Retrieved from https://www.hsdl.org/?abstract\&did=10755

JCoS. (2015). The National military strategy of the United States of America 2015. Retrieved from https://www.jcs.mil/Portals/36/Documents/Publications/2015 National Military Strategy.pdf

JCoS. (2018). Description of the National military strategy 2018. Retrieved from https://www.jcs.mil/Portals/36/Documents/Publications/UNCLASS_2018_National_Military_St rategy_Description.pdf

KA. (2005). Atkurtai Krašto apsaugos sistemai - 15 metų.

Kažerskas, R., Brencius, A., \& Vitkauskas, A. (2012). Karinès jūru pajègos, istorijos metraštis . Vilnius,: KAM.

Lehti, M. (2007). Protégé or go-between? The role of the Baltic States after 9/11 in EU-US relations. Journal of Baltic Studies, 38(2), 127-151.

LK. (2019). Patvirtintas ilgalaikis Lietuvos ir JAV karinio bendradarbiavimo planas. Retrieved from http://kariuomene.kam.lt/lt/naujienos_1887/patvirtintas_ilgalaikis_lietuvos_ir_jav_karinio_bendr adarbiavimo planas.html?pbck $=20$

LMoD. (1999). Sutartis tarp Lietuvos Respublikos Krašto apsaugos ministerijos ir Jungtinių Amerikos Valstijų Gynybos departamento nacionalinès vaizdų ir kartografijos agentūros dèl bendradarbiavimo globalinès geoerdvinès informacijos ir paslaugų srityje. Retrieved from http://kam.lt/download/19463/jav\%20geoerdvine\%20info-liet029.pdf

LMoD. (2004). The military strategy of the Republic of Lithuania. Retrieved from https://css.ethz.ch/en/services/digital-library/publications/publication.html/15267

LMoD. (2005). Krašto apsaugos ministerijos 2005-2007 metų sutrumpintas strateginis veiklos planas . Retrieved from http://www.elibrary.lt/resursai/LR ministerijos/Strategija/KAM-2005planas.pdf.

LMoD. (2006). Krašto apsaugos ministerijos 2006-2008 metų sutrumpintas strateginis veiklos planas . Retrieved from https://eseimas.lrs.1t/portal/legalAct/lt/TAD/e2d83ca0634a11e5b316b7e07d98304b?jfwid=iwhzppmvk.

LMoD. (2009a). Guidelines of the Minister of national defence for 2009-2014. Retrieved from https://www.files.ethz.ch/isn/156884/Lithuania\%20guidelines eng.pdf.

LMoD. (2009b). Krašto apsaugos ministerijos 2009 metų sutrumpintas strateginis veiklos planas. Retrieved from https://e-seimas.Irs.lt/portal/legalAct/lt/TAD/TAIS.339224?jfwid=-m92g8m3oo

LMoD. (2010a). Dél Krašto apsaugos ministerijos 2010-2012 m. Strateginio veiklos plano tvirtinimo. Retrieved from http://kam.lt/download/14304/strateginis

LMoD. (2010b). Lithuania advocates renewed and viable alliance. Retrieved from http://kam.lt/en/news 1098/news archives/2010 news archive 2010/news archive 2010 _10/lithuania_advocates_renewed_and_viable_alliance.html?pbck $=30$

LMoD. (2011a). Dèl Krašto apsaugos ministerijos 2011-2013 m. strateginio veiklos plano tvirtinimo. Retrieved from http://kam.lt/download/25993/kas\%2020112013\%20m.\%20strateginis\%20veiklos\%20planas.pdf 
LMoD. (2011b). USA allocate half of million USD to destroy outdated and unused ammunition reserve. Retrieved from http://kam.lt/en/news_1098/news_archives/news_archive_2011/news_archive_2011_02/usa allocate half of million usd to destroy outdated and unused ammunition reserve.h tml?pbck $=0$

LMoD. (2012a). Dèl Krašto apsaugos sistemos 2012-2014 metų strateginio veiklos plano patvirtinimo. Retrieved from http://kam.lt/download/25987/kas\%202012-

2014\%20m.\%20strateginis\%20veiklos\%20planas.pdf

LMoD. (2012b). Guidelines of the Minister of national defence for 2012-2017. Retrieved from https://kam.lt/download/30609/guidelines\%20of\%20the\%20minister\%20of\%20national\%20defe nce\%20for\%202012-2017.doc

LMoD. (2012c). The military strategy of the Republic of Lithuania. Retrieved from https://www.files.ethz.ch/isn/167339/THE\%20MILITARY\%20STRATEGY\%20of\%20the\%20R epublic\%20of\%20Lithuania.pdf

LMoD. (2014a). Dèl Krašto apsaugos sistemos 2014-2016 metų strateginio veiklos plano patvirtinimo. Retrieved from http://kam.lt/download/44872/kas\%2020142016\%20m.\%20strateginis\%20veiklos\%20planas\%20(2).pdf

LMoD. (2014b). A delegation of U.S. Senators carried out a visit at the Ministry of national defence. Retrieved from http://kam.1t/en/news_1098/news_archives/news_archive_2014/news_archive_2014__04/a_delegation_of_u.s._senators_carried_out_a_visit_at_the_ministry_of_national_defence.ht ml?pbck=20

LMoD. (2014c). Guidelines of the Minister of national defence for 2014-2019. Retrieved from https://kam.lt/download/40910/v-31\%20gaires_en_pataisytos.docx

LMoD. (2014d). Minister of National defence J. Olekas met with Secretary of the U.S. army. Retrieved from http://kam.lt/en/news 1098/news archives/news archive 2014/news archive 2014 _05/minister_of_national_defence_j._olekas_met_with_secretary_of_the_u.s._army.html?pbck= $\underline{20}$

LMoD. (2016a). Guidelines of the Minister of national defence for 2016-2021. Retrieved from https://kam.lt/download/40910/v-31\%20gaires en pataisytos.docx

LMoD. (2016b). The military strategy of the Republic of Lithuania. Retrieved from https://kam.lt/download/51934/lt\%20military\%20strategy\%202016.pdf.

LMoD. (2017a). Pasirašyta sutartis dèl vidutinio nuotolio oro erdvės gynybos sistemų „NASAMS“ pirkimo. Retrieved from

https://kam.lt/lt/naujienos_874/aktualijos_875/pasirasyta_sutartis_del_vidutinio_nuotolio_oro_er dves gynybos sistemu nasams pirkimo.html

LMoD. (2017b). The agreement on the status of U.S. forces on the territory of Lithuania ratified by the Parliament. Retrieved from http://kam.lt/en/news_1098/news_archives/news_archive_2017/news_archive_2017__02/the_agreement_on_the_status_of_u.s._forces_on_the_territory_of_lithuania_ratified_by_the _parliament.html?pbck=10

LMoD. (2017c). Dél Krašto apsaugos sistemos 2018-2020 metų strateginio veiklos plano patvirtinimo. Retrieved from http://kam.lt/download/60180/kas\%2020182020\%20m.\%20strateginis\%20veiklos\%20planas\%2 0v-1159.pdf

LMoD. (2017d). Guidelines of the Minister of national defence for 2017-2022. Retrieved from https://kam.lt/download/57184/gaires\%202017-2022.pdf. 
LMoD. (2019a). The Lithuanian Armed forces is buying anti-UAV equipment. Retrieved from http://kam.lt/en/news 1098/current issues/the lithuanian armed forces is buying antiuav_equipment.html

LMoD. (2019b). De-icing equipment to be bought for the Lithuanian Air force air base in Šiauliai. Retrieved from http://kam.lt/en/news 1098/news archives/new archive 2019/news archive 2019 - 01/deicing_equipment_to_be_bought_for_the_lithuanian_air_force_air_base_in_siauliai.html?pbck=0 \&_cf_chl_jschl_tk_=7003c7d3f4592248f2c98f78329f1acf18ffe56d-1589086183-0Ac1pXkXbRZgXJmqriKDn5heSozuaniLlCGKozSA_W7Ne3bDGwzzI5tmPg1yNWutJW6umnYaONFFgSpAyqveYtk3WzX12nRDsYGj3mAZ3L3bCqC5vF PyhkDwbI868HgQ16iJUojAT8U TZdmclRwg-JgP2NxYL04NjE7d5XzrVi0vHEWe_hs-WMtQZiDtThMD6adODEOjApE3 4qeddWR7aNz--KPVLhIGfilXwk4RNzJhjQRy2cVu9RirezPV_899oh9dNHqCJXV1R_DdqVlKP-9RT5v86dBRu8RUDAYxDQLSZgzljH1ZW3SE1lldUWzF-uFrD_kUFYxXm6tbrRM68Zydfbn88on-LnRS0B-

CpUtnwoHBi9bZ7oamAjrjOl0HT1PcyB7iuoicnjOiv9e0JwNuEXuONet5Bg186jox49pf1vOQgd EhpQTH ds1TRTvnCfJfwOnk5eC9y2-eYf9oCaeOuCaV3NNmbYGLDwtqG3L67vd7M5Nb41Pcy7dkduYsFASDuSnZelI39b_5cdwYy3zZCkdSQ17xO9U

LMoD. (2019c). Dèl Krašto apsaugos sistemos 2019-2021 metų Strateginio veiklos plano patvirtinimo. Retrieved from http://kam.lt/download/67635/v-1102\%20patvirtintas.pdf

LMoD. (2019d). The Lithuanian MoD and the U.S. signed a procurement contract for buying radio communication equipment for the Lithuanian Armed forces. Retrieved from http://kam.1t/en/news_1098/news_archives/new_archive_2019/news_archive_2019__06/the_lithuanian_mod_and_the_u.s._signed_a_procurement_contract_for_buying_radio_com munication equipment for the lithuanian armed forces.html?pbck=10

LMoD. (2019e). Long-term U.S.-Lithuania cooperation plan has been approved. Retrieved from http://kam.lt/en/news_1098/news_archives/new_archive_2019/news_archive_2019_-_04/longterm_u.s.-lithuania_cooperation_plan_has_been_approved.html?pbck=20

LMoD. (2019f). Pasirašyta sutartis dèl šarvuotujų visureigių įsigijimo. Retrieved from https://kam.lt/lt/naujienos 874/archyvas 930/ziniu archyvas 2019 metai/ziniu archyvas 201911/pasirasyta_sutartis_del_sarvuotuju_visureigiu_isigijimo.html?pbck=20

LMoD. (2019g). U.S.-manufactured Javelin anti-tank missile system stocks of the Lithuanian Armed forces supplemented. Retrieved from http://kam.lt/en/news_1098/news_archives/new_archive_2019/news_archive_2019___02/u.s.manufactured_javelin_antitank missile system stocks of the lithuanian armed forces supplemented.html?pbck $=0$

LMoD. (2020). 2008 - 2019 MOD budget dynamic. Retrieved from http://kam.lt/en/budget $1065 . \mathrm{html}$

LRP. (2002). President Adamkus meets US president Bush. Retrieved from http://adamkus.president.lt/en/one.phtml?id=2649

LRP. (2014a). Four Presidents discussed regional security. Retrieved from https://www.lrp.lt/en/media-center/news/18860

LRP. (2014b). Security of the Baltic countries is the United States' unwavering commitment. Retrieved from https://www.lrp.lt/en/media-center/news/security-of-the-baltic-countries-is-theunited-states-unwavering-commitment/18939

LRP. (2017a). Aggressive neighborhood of Lithuania is in focus of U.S. Congress as well. Retrieved from https://www.lrp.lt/en/media-center/news/28333 
LRP. (2017b). Dalia Grybauskaitė directly presented to Donald Trump specific threats to Lithuania. Retrieved from https://www.lrp.lt/en/media-center/news/28007

LRP. (2017c). The focus of the U.S. is on security of the Baltic States. Retrieved from https://www.lrp.lt/en/media-center/news/the-focus-of-the-u.s.-is-on-security-of-the-balticstates/28352/?

Männik, E. (2013). The evolution of Baltic security and defence strategies. Apprenticeship, Partnership, Membership: Twenty Years of Defence Development in the Baltic States, , 13.

Metha, A. (2020). US approves $\$ 7.5$ billion in foreign weapons sales in one day. Retrieved from https://www.defensenews.com/global/the-americas/2020/07/06/us-approves-75-billion-inforeign-weapon-sales-in-one-day/

Miniotaite, G. (2007). The normative construction of the military in Lithuania. Peace Research Institute Frankfurt, I(14)

Mix, D. E. (2020). Estonia, Latvia, and Lithuania: Background and U.S.-Baltic relations. Retrieved from https://crsreports.congress.gov/search/\#/?termsToSearch=R46139\&orderBy=Relevance

MoFA. (2020). Apie ambasadą. Retrieved from https://usa.mfa.lt/usa/lt/atstovybe/apie-ambasada

Norkus, R. (1999). The US role in Lithuania's foreign and security policy. Lithuanian Foreign Policy Review, (3), 13-29.

Obama, B. (2010). National security strategy. Retrieved from https://obamawhitehouse.archives.gov/sites/default/files/rss_viewer/national_security_strategy.p df

Obama, B. (2015). National security strategy. Retrieved from http://nssarchive.us/wpcontent/uploads/2020/04/2015.pdf

OH. (2020). A guide to the United States' history of recognition, diplomatic, and consular relations, by country, since 1776: Lithuania. Retrieved from https://history.state.gov/countries/lithuania

Orenius, A. (2015). 1990-2002 m. Lietuvos Krašto apsaugos politikos raidos analizè. Viesoji Politika Ir Administravimas, 6

Otzulis, V., \& Ozoliņa, Ž. (2017). Baltijos šalių gynybos strategijos formavimas: Priimančiosios šalies parama. Lietuvos Metine Strateginè Apžvalga, 15, 75-97.

Palavenis, D. (2021). Defense industry in Lithuania. case study of the Lithuanian iron triangle through an interconnectivity map framework, Journal of Baltic Studies (will be released).

Radio Liberty. (1997). Newsline - October 17, 1997. Retrieved from https://www.rferl.org/a/1141518.html

Seimas. (1993). Svarbesnieji valstybės atstatymo 19900311 - 19921025 įvykiai. Retrieved from https://www.lrs.lt/datos/kovo11/ivykiai.htm

Seimas. (2002a). Lietuvos Respublikos vyriausybės ir Jungtinių Amerikos Valstijų vyriausybès susitarimas dèl bendradarbiavimo masinio naikinimo ginklų platinimo prevencijos srityje ir dèl gynybos bei karinių santykių plètojimo. Retrieved from https://eseimas.lrs.lt/portal/legalAct/lt/TAD/TAIS.211278

Seimas. (2002b). National security strategy of the Republic of Lithuania. Retrieved from http://stratobs.eu/docs/data/documents/files/137.pdf.

Seimas. (2002c). Susitarimas tarp Lietuvos Respublikos Vyriausybės ir JAV Vyriausybès dèl ginkluotès neperdavimo trečiosioms šalims. Retrieved from https://eseimas.lrs.lt/portal/legalAct/lt/TAD/TAIS.193575

Seimas. (2005). Resolution on the approval of the National security strategy. Retrieved from https://css.ethz.ch/en/services/digital-library/publications/publication.html/156885

Seimas. (2010). Protokolas, kuriuo iš dalies keičiamas ir pratęsiamas Lietuvos Respublikos Vyriausybės ir Jungtinių Amerikos Valstijų Vyriausybės susitarimas dèl bendradarbiavimo masinio naikinimo ginklų platinimo prevencijos srityje ir dėl gynybos bei karinių santykių 
plètojimo. Retrieved from https://e-

seimas.lrs.lt/portal/legalAct/lt/TAD/TAIS.373156?jfwid=mmceo2rtk

Seimas. (2012). Amending the Seimas of the Republic of Lithuania resolution on the approval of the National security strategy. Retrieved from

https://www.bbn.gov.pl/ftp/dok/07/LTU_National_Security_Strategy_2012.pdf.

Seimas. (2017a). Dèl Nacionalinio saugumo strategijos patvirtinimo. Retrieved from https://www.etar.lt/portal/lt/legalActEditions/TAR.2627131DA3D2

Seimas. (2017b). Lietuvos Respublikos Vyriausybės ir Jungtinių Amerikos Valstijų vyriausybės susitarimas dèl bendradarbiavimo gynybos srityje. Retrieved from https://www.etar.1t/portal/lt/legalAct/fe1769b0032511e78034be159a964f47

Seimas. (2018). Dèl Lietuvos Respublikos Seimo 2006 m. liepos 4 d. nutarimo Nr. X-743 „Dėl Krašto apsaugos sistemos plètros programos patvirtinimo" pakeitimo. Retrieved from https://eseimas.lrs.1t/portal/legalAct/lt/TAD/6684a2510cd011e98a758703636ea610

Seimas. (2019). Lietuvos Respublikos Nacionalinio saugumo pagrindų įstatymas. Retrieved from https://e-seimas.lrs.lt/portal/legalActEditions/lt/TAD/TAIS.34169

Šešelgyte, M. (2013). A midget warrior: Security choices of Lithuania. Defence and Security for the Small,

SIPRI. (2019). Military expenditure by country, in local currency, 1988-2019. Retrieved from https://www.sipri.org/sites/default/files/Data\%20for\%20all\%20countries\%20from\%201988\%E2 $\% 80 \% 932019 \% 20$ in\%20local\%20currency.pdf

SIPRI. (2020). Trade registers. Retrieved from http://armstrade.sipri.org/armstrade/page/trade_register.php

Stankevičius, Č. (1996). Enhancing security of Lithuania and other Baltic States in 1992-94 and future guidelines. Retrieved from https://www.nato.int/acad/fellow/94-96/stankevi/index.htm

Svan, J. H., \& Vandiver, J. (2019). With Lithuania pact, US signals increased military role near Russia. Retrieved from https://www.stripes.com/news/europe/with-lithuania-pact-us-signalsincreased-military-role-near-russia-1.575661

Trainauskienè, S. (2013). Transatlantic relations and Lithuania: Unfinished issues of security. Lithuanian Annual Strategic Review, 11(1), 55-79.

Trump, D. J. (2017). National security strategy of the United States of America. National Security Strategy of the United States of America,

Urbelis, V. (2003). US strategy towards Lithuania: A regional approach. Lithuanian Foreign Policy Review, (11-12)

Urbelis, V. (2005). Lietuvos vieta JAV didziojoje strategijoje Generolo Jono Zemaicio Lietuvos karo akademija.

WH. (1990). A national security strategy for the United States. Retrieved from https://nssarchive.us/national-security-strategy-1990/

WH. (1991). A national security strategy for the United States. Retrieved from https://www.hsdl.org/?abstract\&did=460714

WH. (1993). A national security strategy for the United States. Retrieved from https://www.hsdl.org/?abstract\&did=460711

WH. (1994). A national security strategy of engagement and enlargement. Retrieved from https://nssarchive.us/national-security-strategy-1994/

WH. (1996). A national security strategy of engagement and enlargement. Retrieved from https://fas.org/spp/military/docops/national/1996stra.htm

WH. (1997). A national security strategy for a new century. Retrieved from https://history.defense.gov/Portals/70/Documents/nss/nss1997.pdf?ver=2014-06-25-121242-623 
WH. (1998). A national security strategy for a new century. Retrieved from https://history.defense.gov/Portals/70/Documents/nss/nss1998.pdf?ver=2014-06-25-121250-857 WH. (1999). A national security strategy for a new century. Retrieved from https://history.defense.gov/Portals/70/Documents/nss/nss1999.pdf?ver=2014-06-25-121300-170

WH. (2000). A national security strategy for a global age. Retrieved from https://history.defense.gov/Portals/70/Documents/nss/nss2000.pdf?ver=2014-06-25-121312-560

WH. (2014). FACT SHEET: The United States and Lithuania - NATO allies and global partners.

Retrieved from https://obamawhitehouse.archives.gov/the-press-office/2014/09/03/fact-sheetunited-states-and-lithuania-nato-allies-and-global-partners

WH. (2016). FACT SHEET: The United States and Estonia, Latvia, and Lithuania - NATO allies and global partners. Retrieved from https://obamawhitehouse.archives.gov/the-pressoffice/2016/08/23/fact-sheet-united-states-and-estonia-latvia-and-lithuania-\%E2\%80\%93-nato$\underline{\text { allies }}$ 
Annex 1

Procurement of U.S. defense articles by Lithuania throughout 1990-2020

\begin{tabular}{|c|c|c|c|c|c|c|}
\hline Equipment & The U.S. manufacturer & $\begin{array}{c}\text { Quantity, } \\
\text { pes }\end{array}$ & $\begin{array}{l}\text { Price, } \\
\text { million } \\
\text { Euro* }\end{array}$ & $\begin{array}{l}\text { Project } \\
\text { time }\end{array}$ & Remarks & Reference \\
\hline Helicopter 'UH-60M Black Hawk' & Sikorsky and GE Aircraft & 6 & 345 & $2020-2024$ & $\begin{array}{c}\text { DoS provided } 27 \text { million Euro funding. } \\
\text { Overall procurement includes additional } 14 \\
\text { engines, } 12 \text { machine guns, equipment, and } \\
\text { ammunition }\end{array}$ & (Metha, 2020) \\
\hline All-terrain vehicle 'L-ATV Oshkosh' & Oshkosh Corporation & 200 & 142 & 2019-2020 & Including maintenance for 2020-2023 & $(\mathrm{LK}, 2019)$ \\
\hline $\begin{array}{l}\text { Medium range ground-based air } \\
\text { defense battery 'NASAMS' }\end{array}$ & $\begin{array}{c}\text { Kongsberg Defense \& } \\
\text { Aerospace, Norway with } \\
\text { Raytheon } \\
\end{array}$ & 2 & 109 & 2017-2020 & $\begin{array}{l}\text { Parts of battery, } 400 \text { pieces of 'AIM-120C' } \\
\text { missiles, and two 'MPQ-64' radars were } \\
\text { provided by the U.S. }\end{array}$ & $\begin{array}{l}\text { (LMoD, 2017a; } \\
\text { SIPRI, 2020) }\end{array}$ \\
\hline \begin{tabular}{|l|l} 
Long-range anti-tank & missiles \\
\cline { 2 - 2 } system 'Jewelin' & launchers
\end{tabular} & $\begin{array}{l}\text { Raytheon-Lockheed } \\
\text { Martin Javelin }\end{array}$ & $\begin{array}{c}210 \\
74\end{array}$ & 49 & $2015-2021$ & $\begin{array}{l}4.5 \text { million Euro is provided as financial } \\
\text { support from the U.S. }\end{array}$ & $\begin{array}{c}\text { (Global Security, } \\
\text { 2015;LMoD, 2019g) }\end{array}$ \\
\hline \multirow{3}{*}{\begin{tabular}{|l|} 
Anti-Unmanned aerial vehicle (UAV) \\
Ammunition stocks \\
De-icing car for 'C17' type airplanes \\
\end{tabular}} & \multirow{4}{*}{ n.d. } & \multirow{9}{*}{ n.d. } & 1.16 & 2020 & Financed by the U.S. DoS & (LMoD, 2019a) \\
\hline & & & 90 & 2018 & \multirow{3}{*}{ Funds provided by the U.S. } & (Howard, 2018) \\
\hline & & & 0.9 & 2019 & & (LMoD, 2019b) \\
\hline $\begin{array}{l}\text { Tactical radio communication } \\
\text { equipment }\end{array}$ & & & 2.7 & n.d. & & (LMoD, 2019d) \\
\hline \multirow{3}{*}{ Signal equipment } & \multirow{3}{*}{ Harris } & & n.d. & 1998 & & $(\mathrm{KA}, 2005)$ \\
\hline & & & 12 & $2002-2003$ & & (Giuseppetti, 2002) \\
\hline & & & 7.9 & 2019 & & (Baltictimes, 2019) \\
\hline Air surveillance system & Lockheed Martin & & n.d. & 1998 & & $(\mathrm{KA}, 2005)$ \\
\hline Not specified & n.d. & & 27 & 2015-2016 & \multirow[t]{3}{*}{ Implemented using ERI funds } & (WH, 2016) \\
\hline \multirow{2}{*}{$\begin{array}{l}\text { Anti-tank system } \\
\text { 'Jewelin' }\end{array}$} & Raytheon-Lockheed & 74 & \multirow{2}{*}{11.3} & \multirow{2}{*}{ 2001-2003 } & & \multirow{7}{*}{ (SIPRI, 2020) } \\
\hline & Martin Javelin & 18 & & & & \\
\hline \multirow{2}{*}{\begin{tabular}{|l|l|} 
Portable surface-to- & missile \\
$\begin{array}{l}\text { air system 'Stinger' } \\
\text { launcher }\end{array}$
\end{tabular}} & \multirow{2}{*}{$\begin{array}{l}\text { Raytheon Missile } \\
\text { Systems }\end{array}$} & 54 & \multirow{2}{*}{28.1} & \multirow{2}{*}{ 2002-2007 } & \multirow{2}{*}{ Includes two 'MPQ-64' radars } & \\
\hline & & 8 & & & & \\
\hline Armored vehicle 'HMMWV' & AM General & 40 & \multirow{3}{*}{ n.d. } & 2004-2005 & 'M1114' version & \\
\hline Turboprop engine 'AE-2100’ & $\begin{array}{c}\text { Rolls-Royce North } \\
\text { America }\end{array}$ & 6 & & 2006-2009 & For 3 'C-27J'aircrafts & \\
\hline UAV 'ScanEagle' & Boeing and Insitu & 5 & & 2012 & & \\
\hline
\end{tabular}

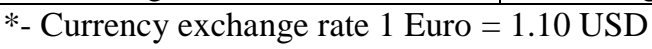


Major armament procurements by the Baltic States from the U.S. from 1990 to 2020 (SIPRI, 2020)

\begin{tabular}{|c|c|c|c|c|c|c|c|c|c|c|}
\hline \multirow[b]{2}{*}{ Defense article } & \multicolumn{3}{|c|}{ Estonia } & \multicolumn{3}{|c|}{ Latvia } & \multicolumn{3}{|c|}{ Lithuania } & \multirow[b]{2}{*}{ Remarks } \\
\hline & 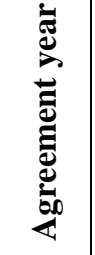 & 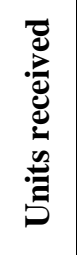 & 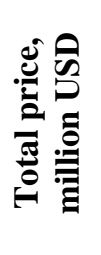 & 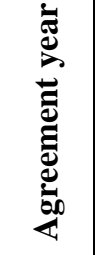 & 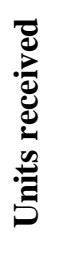 & 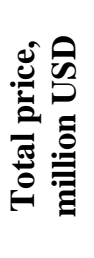 & 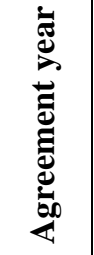 & 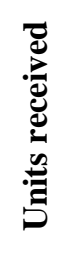 & 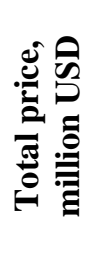 & \\
\hline Cargo ship 'Balsam' & 1997 & 1 & n.d. & & & & & & & Second-hand \\
\hline Light helicopter 'R-44' & 2001 & 4 & 2 & & & & & & & Aid \\
\hline Helicopter 'S-70/UH-60L Black Hawk' & & & & 2018 & 4 & 200 & 2020 & 6 & 380 & \\
\hline Light transport aircraft 'M28 Skytruck' & 2017 & 2 & n.d. & & & & & & & Aid \\
\hline Turbo propeller 'AE-2100' & & & & & & & 2006 & 6 & n.d. & For 3 Italian planes 'C-27J' \\
\hline UAV 'ScanEagle' & & & & & & & 2012 & 5 & n.d. & \\
\hline \multirow{3}{*}{ Air search radar 'TPS-77' } & 2001 & 1 & 12 & 2001 & 1 & 13 & & & & \multirow{2}{*}{ For 'BALTNET' air surveillance network } \\
\hline & & & & 2007 & 2 & 44 & & & & \\
\hline & & & & 2015 & 3 & n.d. & & & & 'MRR' version \\
\hline \multirow{2}{*}{ Air search radar 'MPQ-64 Sentinel' } & & & & 2015 & 4 & n.d. & 2002 & 2 & n.d. & LTU: for 'Stinger' system \\
\hline & & & & & & & 2016 & 2 & n.d. & For 'NASAMS' systems \\
\hline Portable surface to air missile 'Stinger' & & & & & & & 2002 & 54 & 31 & \\
\hline \multirow{3}{*}{ Anti-tank missile 'Javelin' } & 2014 & 240 & n.d. & & & & 2001 & 74 & 10 & \\
\hline & & & & & & & 2016 & 36 & n.d. & \\
\hline & & & & & & & 2018 & n.d. & n.d. & \\
\hline Armored Personnel Carrier 'Cougar' & & & & 2010 & 8 & n.d. & & & & \\
\hline Armored vehicle 'HMMWV' & & & & 2010 & 40 & n.d. & 2004 & 40 & n.d. & $\begin{array}{l}\text { LVA: Second-hand; used in Afghanistan } \\
\text { LTU: 'M1114' version }\end{array}$ \\
\hline Armored vehicle 'L-ATV Oshkosh' & & & & & & & 2019 & 200 & 170.8 & \\
\hline
\end{tabular}

